\title{
EL DERECHO DE PETICIÓN
}

LUCRECIO REBOLLO DELGADO

Profesor de Derecho Constitucional de la UNED 


\section{SUMARIO}

INTRODUCCIÓN. 1. LOS ORIGENES DEL DERECHO DE PETICIÓN. 1.1. Los interdicta en el Derecho Romano. 1.2. El monarca como juez supremo y destinatario de peticiones. 1.3. El Sahib al-mazalim (Señor de las injusticias). 1.4. El Derecho de petición en las primeras Cortes. 1.5. El desuso del derecho de petición. 1.6. El reconocimiento constitucional. 2. LA LEY 22/1960, DE 22 DE DICIEMBRE, REgULAdORA dEL DERECHO DE PETICIÓN. 3. EL DERECHO DE PETICIÓN EN LA CONSTITUCION DE 1978 Y SU DESARROLLO LEGISLATIVO. 3.1. Contenido esencial $y$ definición del derecho de petición. 3.2. Naturaleza jurídica. 3.3. Delimitaciones jurídicas entre petición y otros conceptos. 3.3.1. Petición y acción. 3.3.2. Petición y reclamación o recurso administrativo. 3.3.3. Petición y solicitud. 3.3.4. Petición y denuncia. 3.3.5. Petición y queja al Defensor del Pueblo o figuras afines de las Comunidades Autónomas. 3.4. Sujetos del Derecho. 3.5. La limitación a los miembros de las Fuerzas Armadas. 4. Requisitos PRoCedimentales en el EJeRCICIO del deRECHO de PETICIÓN. 4.1. Contenido y requisitos formales de la petición. 4.2. Tramitación de las peticiones. 4.3. Obligaciones del destinatario de la petición admitida a trámite. 4.4. Protección jurisdiccional del derecho de petición. 5. EL DERECHO DE PETICIÓN EN OTROS ORDENAMIENTOS JURÍdICOSY EN LA UNIÓN EUROPEA. 5. 1. Reino Unido. 5.2. Estados Unidos. 5.3. Alemania. 5.4. Francia. 5.5. Italia. 5.6. Unión Europea. 6. CONCLUSIONES. 


\title{
EL DERECHO DE PETICIÓN
}

POR

\section{LUCRECIO REBOLLO DELGADO}

\author{
Profesor de Derecho Constitucional de la UNED
}

\section{INTRODUCCIÓN}

No son pocas las ocasiones en que he reflexionado sobre la conveniencia o no de un estudio desde la perspectiva constitucional, del derecho de petición. Las aproximaciones doctrinales a este derecho, están capitalizadas por una visión administrativa del mismo, y no son pocos los constitucionalistas que entienden a este derecho como residual. Se debe ello, sin duda, a que este derecho fundamental canaliza únicamente pretensiones que son graciables, o que en todo caso, no hay en ellas una pretensión jurídica. Pero conviene recordar, que el jurista, lo que nunca debe ser es totalitarista, es un grave error pensar que nada existe o tiene importancia fuera de lo que no tiene contenido jurídico.

En todo caso, convergen en este derecho circunstancias substantivamente curiosas. Una primera viene constituida porque a pesar de ser un derecho fundamental con reconocimiento constitucional en la Sección Primera, del Capítulo II, del Título I, de la Constitución de 1978 , no tiene desarrollo legislativo hasta pasados veintitrés años (Ley Orgánica 4/2001, de 12 de diciembre, reguladora del derecho de petición). Ello implica la vigencia de una ley preconstitucional, nada menos, que de 1960 (Ley 92/1960, de 22 de diciembre). La segunda, y quizás más llamativa, viene constituida por la escasa aportación de la doctrina constitucional a este derecho, máxime, teniendo en cuenta que es el origen de derechos que en la actualidad consideramos fundamento del orden social y sin los cuales no sería posible un Estado social y democrático de Derecho. 
Parece que el Derecho de petición es una reliquia constitucional, que se conserva como agradecimiento a lo mucho que ha significado en la relación del ciudadano con el poder. Pero no es ésta una visión aceptable en la actualidad, y argumento de ello es este trabajo, pero para simplificar en un inicio, baste con afirmar que en ningún Estado sobran los mecanismos que facilitan la comunicación y la participación del ciudadano en el poder público.

Parece haber en la doctrina, una especial virulencia contra este derecho. Refiere Tambaro que uel derecho de petición, que tiene una historia no menos antigua y no menos gloriosa que todas las otras garantías constitucionales, se viene convirtiendo en los últimos tiempos en una figura secundaria» ${ }^{1}$. Más dura aún, es la opinión de García Escudero, para quien «es un derecho perfectamente inútil y que se configura en muchos casos como simple desahogo de desahuciados $y$, en su vertiente pública, como válvula que se abre a arbitristas y como expresión de extravagantes" ${ }^{2}$. Por su parte, Basile critica el grado otorgado de protección, que le parece exagerado con respecto a otros derechos, de esta forma entiende que "es absurdo que derechos fundamentales de importancia, como el derecho de status del ciudadano, deban considerarse en menos que el inocuo e inútil derecho de petición... es absurdo que contra un acto tan grave como la privación de la ciudadanía... no se pueda interponer recurso de amparo, mientras que sí se pueda contra cualquier pequeña restricción del inútil derecho de petición» ${ }^{3}$.

Ante este panorama, creo muy conveniente la aportación de una visión desde el Derecho Constitucional, del derecho de petición, que justifique su necesidad, que ponga de manifiesto sus posibilidades, que las tiene, y que realice una lectura actual del mismo, en definitiva, el fin de este trabajo no es otro, que argumentar la importancia y trascendencia que el derecho de petición conserva hoy en un ordenamiento jurídico como el nuestro.

1 TAMBARO, I.: “Los derechos públicos subjetivos y las Constituciones modernas", Revista de Legislación y Jurisprudencia, Madrid, 1911, pág. 157.

2 GaRcía Escudero, J. M.: "El artículo 29", en la obra dirigida por Alzaga VILLAMIL, O.: Comentarios a las leyes políticas. Constitución española de 1978, tomo III, Madrid, 1983, pág. 246.

3 BASILE, S.: "Los valores superiores, los principios fundamentales y los derechos y libertades públicas", en la obra de PEDRIERI, A. y García DE ENTERRÍA, E.: La Constitución española de 1978, Madrid, 1980, pág. 280. 
A lo manifestado hemos de añadir, que en fechas muy recientes, se ha desarrollado por fin, el artículo 29 de la Constitución vigente. De esta forma, la Ley Orgánica 4/2001, de 12 de noviembre (BOE $n .^{\circ} 272$, de 13 de noviembre de 2001), pone término a un vacío legal que estaba supliendo una ley preconstitucional.

\section{LOS ORÍGENES DEL DERECHO DE PETICIÓN}

A pesar de la importancia histórica de este derecho, no es fácil rastrear sus orígenes, y aún menos, concretar el surgimiento o reconocimiento primigenio. Se agrava esta circunstancia además, porque la terminologia es confusa. Hay autores y documentos que refieren el término queja, otros el de reclamación o de solicitud, incluso se confunde con un genérico derecho de defensa. Si a ello añadimos que el derecho de petición está en el origen de un considerable número de los que hoy denominamos derechos fundamentales (como la iniciativa legislativa, el derecho de petición a las Cámaras, las acciones procesales, entre otros muchos), nos encontramos con una verdadera dificultad a la hora de establecer de forma concreta el origen y la forma de aparición de este derecho. Por contra, puede afirmarse con rotundidad que es un derecho de general reconocimiento, y como afirma Rodríguez de Cepeda uel derecho de petición existe en todas partes, lo mismo bajo el despotismo oriental, que bajo las instituciones representativas de Europa» 4 .

Conviene en este apartado, y por lo anteriormente manifestado, establecer unos criterios mínimos que encaucen la búsqueda de antecedentes. Estos han de facilitarnos además, la diferenciación con derechos similares y en todo caso, ser útiles para saber discernir si nos encontramos ante un verdadero derecho de petición. Estos a mi juicio se concretan en lo siguiente:

1. Reconocimiento jurídico del derecho: la norma jurídica es la que atribuye al individuo derechos o facultades, en definitiva le posibilita satisfacer una pretensión. El reconocimiento normativo sustantiva las pretensiones personales.

2. Como consecuencia inmediata del reconocimiento jurídico, y para hacerlo efectivo, han de establecerse los mecanismos

4 Rodríguez de CEPEdA: Elementos de Derecho Público español, Madrid, 1842, pág. 254. 
procesales necesarios para su efectividad. De nada sirve el más solemne de los reconocimientos normativos, si no se posibilita la eficacia real de un derecho.

3. Un tercer elemento ha de ser la verificación de los requisitos del concepto de derecho subjetivo. La fundamentación de estos es la posibilidad de exigencia del ciudadano al poder público establecido.

4. También ha de constatarse la efectividad de la actuación del poder público en plasmar la petición en caso de ser atendida, o entenderla ajustada a derecho, ya que de lo contrario, nos encontraríamos ante un elemento meramente retórico.

Estos cuatro elementos nos permiten saber ¿qué buscamos? y nos ayudan a eliminar aquello que, aun presentando caracteres similares, no es propiamente un derecho de petición.

\subsection{Los interdicta en el Derecho Romano}

Los interdicta son órdenes del Pretor que tienen en esencia tres finalidades; una exhibición, una restitución o una prohibición. Como afirma Iglesias, tienen "el carácter de providencias administrativas urgentes, en cuanto persiguen mantener una situación o el que se obtenga un determinado comportamiento" ${ }^{5}$. De esta forma el magistrado ordena una específica conducta, sin necesidad de mayor averiguación, bajo el supuesto de que la petición formulada se funda en hechos o derechos dignos de ser protegidos jurídicamente. El interdicta podía tener un efecto positivo, es decir, se cumple lo acordado en él, en este caso se zanjaba la cuestión, dado que el peticionario había sido satisfecho. Pero podía darse el caso contrario, y de ser así, había de recurrirse a un iudicium, o procedimiento judicial.

También reconoce el Derecho'Romano un procedimiento especial, como es la apelación al Emperador. Dado que la justicia se imparte en su nombre, aquél puede, en cualquier momento, avocar el proceso para sí. Esta es la denominada cognitio caesaris. De esta forma, era el máximo poder público quien atendía la petición.

5 IGLESIAS, J.: Derecho Romano. Instituciones de Derecho privado, Ariel, 8. ed., Barcelona, 1983, pág. 227. 


\subsection{El monarca como juez supremo y destinatario de las peticiones}

También en la España visigoda el monarca es el juez supremo del reino, es la última instancia en cualquier clase de conflictos, si bien con un fundamento distinto al de los emperadores romanos, y que no es otro, que el origen divino del poder que los reyes administran. De esta forma, son muchos los textos legales y literarios que reconocen al Rey como vicario divino del poder $y$ delegado terrenal de una autoridad superior. A ello hay que añadir que el poder ha de ser administrado para la consecución del bien común, para alcanzar la salus populi. Para lograr estos objetivos, el Rey debe atenerse a los límites marcados por las leyes y someterse a unas normas morales. En palabras de S. Isidoro "eres Rey si obras rectamente, si no, no lo eres" ${ }^{6}$. La influencia religiosa no alcanza únicamente al origen divino del poder real, sino también a la forma de ejercerlo. El Rey ha de reunir las virtudes propias de todo buen cristiano, es decir; fe, esperanza y caridad. También habrá de hacer gala de las virtudes cardinales: prudencia, justicia, fortaleza y templanza, y estas habrán de estar presentes en el ejercicio de su función.

Este obrar recto, se transmite en la España visigoda a través de la estructuración del poder (Aula Regia, Duques, Condes y autoridades locales). También conocemos que la consolidación del régimen territorial se realizó a costa de las ciudades. En ellas, las dos máximas autoridades en el ámbito jurisdiccional eran el Curator y el Defensor Civitatis. Éste último, era el encargado de recibir peticiones al respecto de causas criminales menores, y en grado dispar, de la recaudación de tributos. Pero las obligaciones de estos órganos no eximen al Rey, de escuchar las peticiones del pueblo y otorgarlas, y así se recoge en el Fuero Juzgo, donde se establece que (EI Rey) «deve catar lo quel ruega tod el pueblo, que estonze aya el provecho del pueblo, quando entendieren que los oye, de lo quel demandan, e que ye lo otorgan' 7 .

Aunque de forma esquemática, existen ya en el s. VI los elementos necesarios para verificar un concepto primario de derecho de petición. La función real tiene un origen divino, actúa en representación de Dios, y ha de hacerlo con arreglo a las normas por él establecidas. Entre ellas destaca la caridad, gracias o mercedes que es potes- 
tad del Rey otorgar. Pero no siempre se ejerce esa actividad de forma directa por el monarca, sino que se delega en diversas autoridades, lo que a su vez implica un reconocimiento normativo, aunque este es en la mayoría de las ocasiones laxo.

\subsection{El Sahíb al-mazalim (señor de las injusticias)}

En la España musulmana también el Príncipe es el supremo magistrado, si bien no existen normas limitadoras de su poder absoluto. Además de las jurisdicciones generales del Gran Cadi y de los jueces provinciales, existen algunas jurisdicciones especiales. A juicio de Escudero "la más importante fue la del "señor de las injusticias" (Sahib al-mazalim), alto magistrado que por delegación del soberano atendía las peticiones de los particulares en casos de violación de derechos, abusos de funcionarios o cualquier tipo de extralimitación del poder" 8 .

Con posterioridad, esta función es asumida por los reyes de taifas, los cuales la ejercen de forma personal y pública. De esta forma, los sultanes nazaries convocaban multitudinarias audiencias públicas, en las que los ciudadanos manifestaban sus quejas, protestas y peticiones, al respecto de cualquier asunto, a la vez que solicitaban la oportuna reparación. A juicio de Escudero, "es apreciable esta práctica en el s. $\mathrm{X}$ e inicios del s. $\mathrm{Xl}_{{ }^{9}}{ }^{9}$.

Esta forma de recibir peticiones se institucionaliza con la reconquista, y de forma concreta pasa a numerosos textos jurídicos de los diversos reinos. Pero del propio carácter de los fueros, no puede deducirse una generalización de su existencia, y hay que hablar más bien de reconocimientos aislados.

\subsection{El Derecho de petición en las primeras Cortes}

En los reinos cristianos surgidos con la reconquista, el Rey ostenta un poder absoluto, pero no lo ejerce en solitario, sino que se hace asesorar y delega funciones, primero en la Curia, y con posterioridad en las Cortes. 
Si bien las Cortes se reúnen desde 1188, es difícil determinar cuales son sus funciones concretas, aunque todas entendieron de los asuntos de interés general. Conviene hacer constar que a partir de esta fecha, se institucionalizan las peticiones locales colectivas, o de forma más concreta de los Concejos, que perdurará hasta la Novísima Recopilación.

Dos son los temas que se repiten en todas ellas; uno el financiero, o mejor expresado, el tributario; y otro el de peticiones al monarca. Resulta curioso observar como el Rey solicitaba tributos y las Cortes aceptaban, en función de las peticiones que aquél estuviese dispuesto a conceder. Esto llevó a establecer de forma cotidiana un orden al tratar los asuntos. Así, en Castilla es usual que se aprobara la aportación económica, antes de que el monarca contestase a las peticiones. Por el contrario, en Aragón, el procedimiento era inverso, de tal forma que la concesión de subsidios al Rey quedaba condicionada de las concesiones previas de aquél. También es cierto, que en las Cortes de Aragón, como recoge Escudero, se da en ocasiones "tan rotunda negativa a otorgar el subsidio, que el Rey opta por marcharse sin responder a los agravios", por el contrario, "en las castellanas... los Reyes obtienen el subsidio con cierta facilidad, y a menudo quedan luego las peticiones sin respuesta satisfactoria, lo que explica que se reiteren como súplica insatisfecha de unas reuniones a otras» ${ }^{10}$.

Las peticiones formuladas al Rey por las Cortes son sumamente dispares. Las hay dirigidas contra instituciones del reino, de unos brazos contra otros, de villas contra ciudades, de los vasallos contra los señores, además de peticiones de mercedes al monarca.

Existe además una especial protección de aquellos que formulan las peticiones, como puede corroborarse en la Ordenanza promulgada por Enrique II en las Cortes deToro de 1371, en la que se establece la obligación en todo el reino de que «no sean osados de impedir ni estorbar las alzadas y apelaciones que los vecinos y moradores de todos y cualesquiera lugares de señorio, y otros cualesquiera que quisieren alzarse y apelar, sintiéndose por agraviados de los Señores de ellos, o de sus Alcaldes o Jueces, para ante Nos en nuestras Audiencias: y a no les hagan mal ni daño alguno por esta razon, ca Nos los tomamos so nuestro seguro amparon.

10 Obra citada, pág. 538. 
El facilitar el acceso a la petición directa al Rey pasará a Las Partidas, $y$ con posterioridad se institucionalizan las audiencias, preestablecidas con día y hora. Estas peticiones son muy genéricas y habitualmente desprovistas de formalismo escrito, y que se expresan en la forma genérica recogida por Juan I «para Nos dar peticiones o decir las cosas que nos quieran decir de bocan.

Las propias Cortes institucionalizan este derecho, convirtiéndose en obligatorio a partir de las Cortes de Madrid de 1329. Esta norma pasará a las Ordenanzas Reales de Castilla de 1484.

\subsection{El desuso del derecho de petición}

La vigencia del derecho de petición va indefectiblemente unida a la fuerza que las Cortes tienen ante el Rey. De esta forma, ya desde mediados del s. XV, hasta prácticamente el inicio del constitucionalismo, las Cortes pierden la potestad de presentar peticiones al Rey, o bien éste no las otorga.

Como puede apreciarse, en las primeras Cortes existe cierta coerción en la petición, se traduce ésta en la necesidad que el monarca tiene de recibir los tributos. Por el contrario, a partir de mediados del $\mathrm{S}$. $X V$, la balanza del poder se inclina a favor del Rey, de forma tal, que la petición es atendida en función de su razonabilidad o de la conveniencia pública del monarca. Además se formaliza su realización, de tal forma que ha de ser necesariamente por escrito. Se pretende con ello, y como afirma Jiménez de Cisneros, «llamar la atención del Rey... sobre las anomalias y abusos cometidos por cualquiera de las autoridades" "1.

Pese a las circunstancias citadas, hemos de hacer mención de una singular forma de realizar peticiones en esta época. Nos referimos a los memoriales realizados por eclesiásticos relativos a la situación de los indios en la colonización de América. La puesta en conocimiento de Las Casas a Carlos $V$ en 1541, de muchos asuntos relacionados con la situación de la población indígena, así como situaciones de corrupción, provocó la destitución de algunos miembros del Consejo de Indias y de otros funcionarios, tanto de la metrópoli como de las colonias.

11 JIMÉNEZ de CISNEROS, F. J.: El derecho de petición y la iniciativa legislativa popular, Madrid, 1980, pág. 8. 
Puede decirse que el padre Las Casas se convirtió en un recapitulador de peticiones, y que ésas se vieron atendidas, dado que un año después, en 1542, se dictan las Leyes Nuevas de Indias, en las que se establece la obligación de que los indios usean muy bien tratados e instruidos en las cosas de nuestra santa fe católica y como vasallos nuestros libres que son....12.

Parece claro al respecto de ésta época, y como afirma López Rodó, que uel derecho de petición va perdiendo importancia durante la Edad Moderna. Ello se debe, en buena parte, al desarrollo de las instituciones judiciales y también a la creciente complejidad de los asuntos de gobierno que retienen la atención del Príncipe» ${ }^{13}$.

\subsection{El reconocimiento constitucional}

La ausencia de uso y de reconocimiento jurídico del derecho de petición se interna en el período constitucional. De esta forma, el Estatuto de Bayona no reconoce derecho alguno identificable con el actual derecho de petición. Por su parte, la Constitución de 1812 reconoce en su artículo $\mathbf{3 7 3}$ un confuso derecho a "representar a las Cortes o al Rey para reclamar la observancia de la Constitución". Se deduce que es un derecho de petición limitado por un contenido material, el incumplimiento constitucional. Pero como afirma García Cuadrado «no dejaron en los años siguientes de presentarse peticiones al Rey Fernando VII y a las Cortes' ${ }^{14}$, es más, se hizo un copioso uso del derecho de petición de forma colectiva. Por ello, el 12 de febrero de 1822, se dicta un Decreto con objeto de que se utilice en "los justos límites", y se prohíbe el uso de este derecho a corporaciones, sociedades y toda clase de personas jurídicas. De esta forma, y como con claridad lo expresa López Rodó, «el liberalismo, que dedica todos sus esfuerzos a aniquilar las instituciones intermedias entre el individuo y el Estado, restringe el ejercicio de un derecho hondamente arraigado en la misma naturaleza del hombre y en la historia de nuestro pueblo» ${ }^{15}$.

12 Recopilación de Leyes de Indias. Consejo de la Hispanidad, Madrid, 1943. Leyes Nuevas de Indias, artículo 30.

13 LOPEZ RODO, L.: «EI derecho de petición. Antecedentes, directrices y discusiones en las Cortes», Documentación Administrativa, n. 40 de 1961, pág. 11.

14 Garcia Cuadrado, A.: “El derecho de petición», Revista de Derecho Politico de la UNED, . $^{\circ} 32$ de 1991, pág. 142.

15 Obra citada, págs. 11 y 12. 
Parecida situación se da con la entrada en vigor del Estatuto Real, que recoge en su artículo 31 la prohibición a las Cortes de deliberar sobre ningún asunto "que no se haya sometido expresamente a su examen en virtud de un Decreto Real». Pese a ello, el artículo siguiente, establece que "queda sin embargo expedito el derecho que siempre han ejercido las Cortes de elevar peticiones al Rey, haciéndolo del modo y la forma que se fijará en el Reglamento".

Habrá que esperar a la Constitución de 1837, para ver reconocido a nivel constitucional, por primera vez en el ordenamiento jurídico español, el derecho de petición. Su artículo 3 establece de forma tajante que utodo español tiene derecho de dirigir peticiones por escrito a las Cortes y al Rey, como determinen las leyes". Con la misma literalidad se reconoce en la Constitución de 1845, y en un artículo posterior, en la Constitución no nata de 1856.

Con la Constitución de 1869 se introducen significativas novedades en el reconocimiento constitucional del derecho de petición. La más destacable es el insertarlo en un artículo, el 17, que se dedica a un conjunto de derechos como son el de emitir libremente ideas y opiniones, el derecho a reunirse pacíficamente, el derecho de asociarse y en un último apartado, se reconoce también el "derecho a dirigir peticiones individual o colectivamente a las Cortes, al Rey y a las Autoridades". Tres son a mi juicio, las novedades más significativas introducidas por la Constitución de 1869 en lo relativo al derecho de petición. La primera viene constituida por la posibilidad de ejercitar el derecho de forma individual o colectiva. El segundo aspecto a destacar es la apertura de los sujetos pasivos de la petición, dado que ahora se pueden dirigir peticiones tanto al Rey como a las Cortes, y también a las Autoridades. Se entiende que estos últimos, son órganos más próximos al ciudadano, y que la Constitución engloba bajo el concepto de Autoridad. Una tercera y última novedad, viene constituida por el carácter garantista del derecho, desconocido hasta la fecha. El artículo 17 comienza estableciendo que «tampoco podrá ser privado ningún español de...n. Tras lo manifestado, puede afirmarse que es en la Constitución de 1869 donde se configura el derecho de petición en su versión más moderna, $y$ donde se le atribuye los caracteres con que llegará hasta la Constitución de 1978.

El proyecto de Constitución de 1873 suprime la forma escrita como única posible (artículo 19) y la Constitución de 1876 introduce la limitación del ejercicio de este derecho a los miembros de cualquier fuerza armada (artículo 13). 
En la Constitución de 1931 desaparece la referencia del Rey, como es lógico, pero también la de las Cortes, siendo sustituidas por "Poderes Públicos y a las Autoridades». Con la vigencia de las Leyes Fundamentales, además del reconocimiento del derecho en el artículo 21 del Fuero de los Españoles, se da el desarrollo legislativo mediante una ley de contenido específico, la Ley de 22 de diciembre de 1960 , reguladora del derecho de petición, que estará vigente hasta su expresa derogación por la Ley 4/2001, de 12 de noviembre, que desarrolla el artículo 29 de la Constitución de 1978.

\section{LA LEY 92/1960, DE 22 DE DICIEMBRE, REGULADORA DEL DERECHO DE PETICIÓN}

El artículo 34 del Fuero de los Españoles afirmaba que las Cortes votarian las leyes necesarias para el ejercicio de los derechos reconocidos en el Fuero. Uno de estos era el derecho de petición, regulado en el artículo 21, que establecía que «Los españoles podrán dirigir individualmente peticiones al Jefe del Estado, a las Cortes, $y$ a las Autoridades". Estos mandatos se cumplen con la ley que ahora estudiamos, la cual delimita sus competencias y facilita su ejercicio.

En fundamento de este derecho, manifiesta López Rodó «que no tiene sólo por objeto alcanzar de los poderes públicos la reparación de un agravio o la corrección de abusos, sino también el promover de abajo a arriba la realización de concretas manifestaciones del bien común", continúa afirmando el autor, que el derecho de petición "es un modo de participación social en el quehacer políticon" ${ }^{16}$.

El artículo 1 reconoce el derecho de petición como «la facultad que corresponde a los españoles para dirigirse a los Poderes Públicos en solicitud de actos o decisiones sobre materia de su competencia». Conviene destacar de su contenido, la amplitud del concepto Poderes Públicos, que abarca desde el Jefe del Estado y las Cortes, pasando por toda la jerarquía de poder provincial y local, hasta incluso las representaciones consulares.

En cuanto a la legitimación, le corresponde a los españoles mayores de edad, y a las personas jurídicas de nacionalidad española, e incluso la mujer casada, puede ejercitar este derecho sin el

16 Obra citada, pág. 9. 
requisito de la asistencia del marido (arts. 3.1 y 2). No obstante, el art. 4 establece limitaciones en cuanto al ejercicio por determinados grupos (Fuerzas Armadas, funcionarios), los cuales habrán de llevar a la práctica este derecho con arreglo a las disposiciones por las que se rigen.

La Ley también pretende un principio de eficacia en el uso del derecho de petición, de tal forma que además de establecer que "de su ejercicio no podrá derivarse perjuicio alguno al peticionario" (art. 1.1), impide que la petición no tenga efecto en caso de que se hubiera dirigido a la autoridad no competente, dado que en este supuesto, deberá remitirla a la que considere que lo es, y ello habrá de ser comunicado al peticionario (art. 7.2). Incluso, va un poco más allá la norma en el ámbito de la efectividad o utilidad de la petición, de forma tal, que si la petición use estimare fundada, se adoptarán las medidas oportunas, a fin de lograr su plena efectividad" (art. 11.1). En el supuesto de que tales medidas "exigiesen dictar una disposición general, se incoará el procedimiento correspondiente, según la jerarquía de la disposición» (art. 11.2).

Como puede apreciarse, el contenido de la Ley 92/1960, facilita el ejercicio del derecho en su plenitud, y lo hace de una forma abierta, lo cual ha posibilitado su vigencia hasta el año 2001. Si bien algunos contenidos estaban derogados por la entra en vigor de la Constitución de 1978, como es el caso de las peticiones específicas a las Cortes (art. $77 \mathrm{CE}$ ), y otros han sido reinterpretados por la jurisprudencia tanto del Tribunal Supremo, como del Tribunal Constitucional, el fundamento último de la norma ha persistido, de ahi su longevidad. La justificación de su existencia, no es otra que el fundamento último del derecho, es decir, dar un cauce al ciudadano para ponerse en contacto con el poder público, y hacerle llegar sus pretensiones de una forma directa. Esta regulación se realizó de forma eminentemente técnica, con carácter administrativo y sin contenidos políticos, ello también ha obrado en favor de su compatibilidad constitucionalidad.

\section{EL DERECHO DE PETICIÓN EN LA CONSTITUCIÓN DE 1978 Y SU DESARROLLO LEGISLATIVO}

En la redacción constitucional, el derecho de petición fue uno de los menos debatidos, $y$ al que menos enmiendas se le introdujeron. De esta forma, el art. 29 del Anteproyecto Constitucional reconoce 
en su apartado primero, que «Todos los españoles tendrán el derecho de petición individual y colectiva, por escrito, en la forma y con los efectos que determine la ley". Esta ausencia de debate y conflicto en la redacción de este derecho ${ }^{17}$, puede deberse en esencia a dos causas. La primera de ellas se justificaría en lo incontrovertible del contenido esencial del derecho, que es heredero, como hemos analizado, de un devenir histórico. La segunda justificación podría encontrarse en una calificación residual del derecho que estudiamos, entendiéndole como una reliquia constitucional, o en todo caso, un derecho con pocas consecuencias de cara al poder público. Si bien esto último parece contradictorio con la ubicación, dentro de la sección primera, del Capítulo II, del Título I, de la Constitución, y como consecuencia de ello, con la protección que se le otorga.

Muy criticado por la doctrina ha sido el hecho de incluirlo en la Sección 1. ${ }^{\mathrm{a}}$ del Capítulo II, del Título I, y no faltan razones para argumentar esta circunstancia. La primera es, sin duda, el agravio comparativo que supone con respecto a otros derechos que afectan de forma más radical a la vida de las personas. No es comparable la lesión del derecho a la vida, a la integridad física y psíquica, a libertades como la ideológica o de expresión, con el derecho de petición. Hubiera sido más acorde la protección, si el que estudiamos, estuviera ubicado en la Sección 2. ${ }^{a}$ o incluso en el Capítulo III. Es más, tampoco hubiera disonado haberlo incluido en elTítulo IV, en lo relativo a la Administración, dado que alli se relacionan derechos tan importantes como los del articulo 103 o 105 b). La segunda argumentación se basa en lo desmesurado de la protección, sobre todo teniendo en cuenta el contenido del derecho, que como veremos, no puede ser en ningún caso una pretensión para la que el ordenamiento jurídico ya tiene establecido procedimiento.

También desde la perspectiva de la lesión de los derechos, queda el de petición relegado, dado que la imposibilidad de ejercitarlo queda suplido en nuestro ordenamiento jurídico por múltiples mecanismos.

Lo manifestado no puede entenderse como argumentos a favor de la poca relevancia jurídica del derecho de petición, cuestión que

17 El art. 33 del Anteproyecto de Constitución recogia el texto que después será definitivamente aprobado, con una sola salvedad, junto al derecho de petición aparece el sustantivo "o reclamación", que fue suprimido en el dictamen de la Comisión Mixta. 
refutaremos más adelante, y únicamente es la constatación de una errónea ubicación constitucional del derecho de petición.

En todo caso, cuando nos referimos al derecho de petición, lo hacemos a un derecho fundamental, cuya vigencia no puede ser suspendida, que requiere para su desarrollo legislativo ley orgánica, y que goza de la protección mediante recurso de amparo.

Como en el estudio de cualquier otro derecho fundamental, nos interesa conocer el contenido esencial del derecho de petición, así como su naturaleza jurídica, para con posterioridad entrar en el análisis del desarrollo legislativo.

Por lo que respecta a la necesidad de desarrollo legislativo con una base constitucional, esta venía requiriéndose desde hacía bastante tiempo. Se constata esta circunstancia, en que el Plan de Modernización de la Administración del Estado, publicado por el Ministerio de Administraciones Públicas en 1994, entre sus propuestas para mejorar la atención del ciudadano establecía como necesidad la de uelaboración de una nueva ley que desarrolle el artículo 29 de la Constitución relativo a tal derecho y el establecimiento de un procedimiento acorde con la Ley $30 / 92$ sobre Procedimiento Administrativo".

Esta propuesta, como es conocido, no se plasmó hasta diciembre de 2001, fecha en la que entra en vigor la Ley Orgánica 4/2001, reguladora del derecho de petición, de cuyos contenidos nos ocupamos en este apartado.

\subsection{Contenido esencial y definición del derecho de petición}

La delimitación del contenido esencial del derecho que estudiamos nos obliga a establecer una definición del mismo, lo cual a su vez hace necesario desligar contenidos del derecho que lo fueron históricamente, pero que en la actualidad no lo son.

Históricamente la petición era el cauce de cualquier tipo de pretensión, ya fuera ésta juridica, individual, de denuncia o con objeto de un interés colectivo. En la actualidad, del derecho de petición se excluye todo ejercicio de un derecho subjetivo o de un interés legítimo especialmente protegido, dado que estas pretensiones tienen una vía jurídica preestablecida. De esta forma, el contenido legal del derecho de petición, como afirma el Tribunal Constitucional habrá de ser «una 
sugerencia o una información, una iniciativa... pero en cualquier caso ha de referirse a decisiones discrecionales o graciables»"18.

De esta forma, la petición ya desde la Ley 92/1960, pierde el carácter jurídico en lo referido a su contenido, pero sigue conservando un marcado carácter político, sobre todo si es colectiva, dado que utiliza en alguna medida a la petición como instrumento de participación ciudadana, como medio de comunicación entre el ciudadano y los poderes públicos, a la vez que también es una forma de canalizar una genérica libertad y una concreta libertad de expresión.

García Cuadrado entiende que el contenido esencial del derecho que estudiamos consiste en el "derecho de toda persona a ser escuchado por quienes ejercen el poder público» ${ }^{19}$. El mismo autor, apunta un aspecto que hace incompleta esta delimitación del derecho, pues manifiesta que "hoy en día el acto de audiencia del peticionario se sustituye por el escrito de petición, pero entonces no existe constancia alguna de que el gobernante "ha escuchado la petición", y por consiguiente, sólo la contestación, también escrita, aceptando o rechazando lo pedido, puede garantizar la efectiva realización del derecho de petición» ${ }^{20}$.

Como puede observarse, en la actualidad el derecho de petición ha ido construyéndose con requisitos suplementarios, con obligaciones, fundamentalmente del destinatario de la petición, a la vez que con garantías, de que la utilización del derecho no provocará perjuicio alguno a quien lo ejercita.

Conviene recordar aquí, que la petición no puede ser únicamente elevar un comentario a la autoridad pública. El núcleo del derecho viene constituido por el petitum. Si el ciudadano únicamente pone en conocimiento un hecho, o expresa una opinión personal, no surge la obligación jurídica del destinatario de contestar, y tampoco de reparar. La petición es una forma de activar el poder público, de ponerlo en funcionamiento, y para ello la petición debe reclamar de forma expresa una actuación de aquél.

Tras lo manifestado, debemos concluir en que el derecho de petición es el derecho que el individuo tiene de pretender de cualquier institución pública, administración o autoridad, una actuación, sobre cual- 
quier asunto, que sea competencia del destinatario, y que no contenga una pretensión coincidente con un derecho o interés legítimo. Partiendo de esta definición, el contenido esencial del derecho queda delimitado por cuatro elementos:

1. Es un derecho de toda persona, a pedir o solicitar algo al poder público.

2. Se ejercita ante cualquier poder público y relativo a cualquier materia de su competencia, para la que no exista un procedimiento jurídico.

3. De su ejercicio no puede derivarse perjuicio alguno.

4. Existe la obligación del destinatario de contestar motivadamente a la petición.

Puede apreciarse, que el contenido esencial de este derecho es reducido, dado que se concreta en los cuatro elementos citados, pero genera dos obligaciones con respecto al destinatario. Una primera se materializa en poner en conocimiento del peticionario la recepción de la petición, y una segunda, que viene constituida por comunicarle al interesado la resolución que se ha adoptado. Ahora bien, como establece elTribunal Constitucional, el ejercicio del derecho no implica «el derecho a obtener respuesta favorable a lo solicitado" 21.

Una vez delimitado el contenido esencial del derecho, puede ofrecerse una definición del mismo, que deberá incluir, necesariamente, los cuatro elementos que lo componen, delimitan y configuran. De esta forma, entendemos por derecho de petición la facultad que todo individuo tiene de dirigirse, ya sea individual o colectivamente, a los poderes públicos, en solicitud de una pretensión al respecto de cualquier materia que no sea un derecho subjetivo, de la cual no puede derivarse perjuicio alguno y que genera la obligación al destinatario de contestarla de forma motivada.

Nada limita el contenido de la petición, dado que como la propia Exposición de Motivos de la Ley Orgánica 4/2001 establece, «las peticiones pueden incorporar una sugerencia, una iniciativa, una información, expresar quejas o súplicas. Su objeto, por tanto, se caracteriza por su amplitud y está referido a cualquier asunto de interés general, colectivo o particular». Ahora bien, como hemos establecido, el petitum, no puede en ningún caso eludir un procedimiento ya esta- 
blecido por el ordenamiento jurídico para reclamarlo. De la misma forma, no puede ser el contenido esencial de la petición la exigencia de cumplimiento de un derecho o de un interés legitimo, ya sea del que realiza la petición o de un tercero.

\subsection{Naturaleza jurídica}

Existe al respecto de la naturaleza jurídica del derecho de petición una histórica confusión que se remonta a la Asamblea Constituyente francesa de 1791. En ella, el Diputado Chapelle se opone a Robespierre en la extensión del ejercicio del derecho. El primero de los diputados argumenta la necesidad de excluir del ejercicio de este derecho a los extranjeros, el segundo, defiende que ha de ser entendido como un derecho universal. En su argumento Chapelle concluye que hay que distinguir entre un derecho de petición, que «es el que tiene el ciudadano activo de expresar sus opiniones al Legislativo, al Rey o a los administradores públicos, sobre asuntos de administración o de organización», y un derecho de queja, que es el derecho de "recurrir que tiene todo hombre que ve lesionado sus intereses particulares".

Como puede apreciarse, en esta fundamentación la legitimación determina el contenido del derecho, así como su naturaleza jurídica. De esta forma el derecho de petición lo ejercitan tan sólo los ciudadanos, su objeto es manifestar opiniones con contenido político, y en consecuencia estamos ante un derecho de participación política. Si quien ejerce la petición es un extranjero, nos encontramos ante un derecho de queja, su contenido es la petición individual de la reparación de un agravio o de un daño causado, y la naturaleza jurídica es encuadrable dentro del concepto genérico de libertad22.

Algunos autores franceses lo clasifican como derecho natural o individual, despojado de carácter político ${ }^{23}$. Por el contrario, en la doctrina italiana encontramos autores que entienden al derecho de petición como un derecho de naturaleza política ${ }^{24}$. Otros autores no

22 Sigue esta argumentación García CuADRADO, en obra citada, pág. 154.

23 Duguit, L.: Traité de Droit Constitutionnel. Les Libertés Publiques, $10 .^{\mathrm{a}}$ ed., París, 1927, págs. 443 y 444.

24 Es el caso de Biscaretti di Rufia, P.: Derecho Constitucional, 3. ${ }^{2}$ ed., Tecnos, Madrid, 1987, pág. 749. 
encuentran una clasificación entre las establecidas y lo encuadran como derecho sui generis, así lo hace Nacci ${ }^{25}$.

En la doctrina española existe una práctica unanimidad en considerar el derecho de petición como derecho público subjetivo, en cuanto que las peticiones se dirigen a los poderes públicos ${ }^{26}$. Algunos autores van un poco más allá, al establecerle además el carácter de derecho de participación política27. Un matiz más concreto le dan aún García de Enterría y Tomás Ramón Fernández, al calificarlo de derecho de participación funcional del administrado en la Administración ${ }^{28}$. De "carácter fundamental y naturaleza polivalente» lo califica Montiel Márquez ${ }^{29}$.

Puede afirmarse que todas las definiciones ofrecidas son válidas $^{30}$, en la medida que ofrecen parte de un todo. Indudablemente que el derecho de petición es un derecho público subjetivo, de igual forma que en alguna medida lo es de participación política y administrativa. Tampoco es menos cierto, que tanto en su uso individual como colectivo, el derecho de petición tiene bastante de medio de canalizar opiniones $y$ en último término de libertad de expresión. A mi juicio, todos estos contenidos pueden englobarse bajo un concepto genérico que no desdibuja los contenidos parciales. Esta calificación no es

25 NACCI, G.: I/ diritto di petizione negli ordinamenti dello Stato e delle regioni, Nápoles, 1979, págs. 46 y 47.

26 Así lo hacen Morodo, R., en obra citada, pág. 92; LUCAS MiRILLO de LA CUEVA, en la voz "Petición", de la Nueva Encliclopedia Jurídica, tomo XIX, pág. 741, y también PeCES-BARBA, G., en su obra La Constitución Española de 1978. Un estudio de derecho y política, Valencia, 1981, págs. 40 y 41, y por último, GARCía CuADRADO, en obra citada, pág. 164.

27 SÁNChez AGESTA, L.: El sistema político de la Constitución española de 1978, 5. ${ }^{a}$ ed., Madrid, 1987, pág. 177; LOPEZ GUERRA, L., en la obra de VV.AA.: Derecho Constitucional, vol. I, pág. 273, y SÁNCHEZ FERRIZ, R.: "El derecho de petición y su ejercicio ante las Cámaras", en la obra de VV.AA. Las Cortes Generales, vol. III, IEF, Madrid, 1987, pág. 2223.

28 Garcia de Enterria, E., y Fernández Rodriguez, T. R.: Curso de Derecho Administrativo, vol. II, $7^{\text {a }}$ ed., Civitas. Madrid, 1995, pág. 93.

29 Montiel Márouez, A.: «El derecho de petición: ¿instrumento de participación directa de los ciudadanos, o manifestación de la función de control?", Cuadernos Constitucionales, núms. 30/31, Universidad de Valencia, Valencia, 2000. pág. 167.

30 Incluso la ofrecida por COLOM PAStOR, B.: El derecho de petición como derecho fundamental, Madrid, 1997, pág. 93, que lo configura como "un derecho para proteger los intereses jurídicos no protegidos en principio por el derechon. 
otra que la que atribuye al derecho de petición una naturaleza participativa en la pretensión del bien común. El derecho de petición, en la actualidad, es un mecanismo de participación ciudadana en el funcionamiento de los poderes públicos $y$ de forma más genérica en la consecución del bien común. El derecho de petición es una vía juridica para la puesta en conocimiento del poder público de hechos, 0 estados de cosas que pueden referirse al funcionamiento de los mismos, pero también de otros ciudadanos. Puede alertar al poder público de un vacío jurídico, de una necesidad de regulación, de funcionamientos o actuaciones deficientes, incluso estando éstos dentro de la legalidad. En definitiva, todos estos contenidos, cuando se canalizan a través del derecho de petición persiguen el objetivo de posibilitar la participación del ciudadano en su entorno, con el fin de mejorarlo.

Es necesario establecer dos vertientes en el derecho de petición, una individual y otra colectiva. En la primera se trata de un derecho al servicio de pretensiones individuales, que pueden constituirse en un instrumento de ayuda al ciudadano en su relación con el complejo sistema administrativo y burocrático. En una Administración prestacional como es la actual, el derecho de petición cubre en gran medida el vacío de la desinformación. Pero a la vez sirve para poner en conocimiento del poder público un conjunto de situaciones que van desde hechos excepcionales a vacios legales.

En la segunda vertiente, la colectiva, el derecho de petición se constituye en un medio de canalizar sentimientos, aspiraciones o pretensiones compartidas por grupos de ciudadanos. La ventaja aquí, es la ausencia de influencias de otras organizaciones sociales con intereses concretos, como pueden ser los partidos políticos, grupos sociales o medios de comunicación.

\subsection{Delimitación jurídica entre petición y otros conceptos}

Al ser el derecho de petición la raiz de un conjunto de derechos constitucionalizados o legalizados hoy, plantea algunos problemas de deslinde con otros términos. Los conceptos que vienen siendo usados de forma habitual como sinónimos incorrectos de petición son los de acción, recurso, denuncia, solicitud, queja e iniciativa legislativa, entre otros. 
El Diccionario de la Real Academia Española de la Lengua, reconoce en la primera acepción del vocablo petición a ula acción de pedir» ${ }^{31}$, y define al peticionario como el "que pide o solicita oficialmente una cosa». En base a esta delimitación semántica, realizaremos la distinción juridica de forma separa en cada caso.

\subsubsection{Petición y acción}

No faltan autores, sobre todo en el ámbito del Derecho Procesal, que establecen una directa correlación semántica y jurídica entre petición y acción. Así Fairén Guillén manifiesta que uuna vez admitido el poder de hacer peticiones a las autoridades públicas, dicho poder se especifica, y ocasiona la formación de diversas especies de derechos; el de accionar (ante los tribunales) es uno de ellos» ${ }^{32}$. Por su parte, Ruiz del Castillo, entiende que ues el derecho de petición el que ha engendrado el derecho de iniciativa en el orden legislativo, como el orden judicial ha engendrado la demandan ${ }^{33}$. Pese a estas afirmaciones, en la actualidad, hay que diferenciar ambos derechos, porque tienen entidad autónoma y reconocimiento jurídico separado, con contenidos y procedimientos distintos.

El elemento capital en la delimitación, es el contenido material de ambos. De esta forma, usamos la acción cuando entendemos que el ordenamiento jurídico protege nuestra pretensión. El fundamento de la acción es una reclamación para que se cumpla la norma, o para que actúe el poder público. En definitiva, "para ejercitar el derecho de acción se exige ser titular de derechos o intereses legítimos y para ejercitar el derecho de petición se exige lo contrario, esto es, no ser titular de derechos o intereses legítimos» ${ }^{34}$. Claros ejemplos de la desnaturalización jurídica del derecho de petición nos da el Tribunal Constitucional, el cual, ante una petición formulada ante él, resuelve

31 La segunda acepción no tiene relevancia jurídica, y la tercera establece como petición "el escrito que se presenta ante un juez».

32 FAIRÉN GUILLÉN, "De nuevo sobre los conceptos de acción y de pretensión", en Revista de Derecho Procesal, n. ${ }^{\circ}$ de 1955, pág. 15. En el mismo sentido se pronuncia GonzAlez PÉREZ, J.: «Régimen jurídico del derecho de petición», Documentación Administrativa, n. 40 de 1961, pág. 17. Y 418.

33 RuIz DEl CASTILlo, C.: Manual de Derecho Político, Madrid, 1939, págs. 417

34 Colom PASTOR, obra citada, pág. 26. 
mediante auto ${ }^{35}$, que su naturaleza jurisdiccional «seria por lo demás incompatible con el puro derecho de petición». Más recientemente, el mismo Tribunal ha manifestado que la petición, uen sentido estricto que aquí interesa no es... una demanda o un recurso.... ${ }^{36}$.

También conviene recordar, que la acción se ejercita ante un órgano de naturaleza jurisdiccional necesariamente, por el contrario la petición puede ser formulada ante cualquier órgano investido de autoridad pública, excluidos los de la naturaleza citada.

\subsubsection{Petición y reclamación o recurso administrativo}

El artículo 3.1 de la vigente Ley Orgánica del derecho de petición establece que uno son objeto de este derecho aquellas solicitudes, quejas o sugerencias para cuya satisfacción el ordenamiento jurídico establece un procedimiento específico distinto regulado en la presente ley». Por el contrario, ha existido una sinonimia entre petición o reclamación. Incluso el Anteproyecto de Constitución establecía en su artículo 33.1 que "todos los españoles tendrán derecho de petición o reclamación...».

Parece claro, que mientras el recurso o la reclamación administrativas requieren un acto previo de un órgano, institución o autoridad, y tienen como objeto modificarlo o impugnarlo, el derecho de petición no necesita de una actuación previa y concreta de ningún organismo, más bien al contrario, su pretensión es que se de aquél. Además, tanto el recurso como la reclamación previa en vía administrativa requieren de un contenido necesario, que está negado al derecho de petición, y que no es otro que un interés legítimo lesionado, o la pretensión de que se cumpla un derecho.

\subsubsection{Petición y solicitud}

La confusión entre el derecho de petición y otros conceptos, normalmente viene generado por la utilización normativa indistinta de los mismos. Es a su vez frecuente, que una vez modificada la nor-

\footnotetext{
35 ATC n. ${ }^{\circ} 46 / 80$, f. j. $10^{\circ}$

36 STC $242 / 1993$, f. j. $10^{\circ}$
} 
ma, se sigue utilizando el concepto. Pero en otras ocasiones, es la misma norma vigente, la que genera la confusión. Así ocurre con los derechos de petición y el concepto de solicitud en la Ley de Régimen Jurídico de las Administraciones Públicas y del Procedimiento Administrativo Común (en adelante LRJAP). Su artículo 43.2 establece que "los interesados podrán entender estimadas por silencio administrativo sus solicitudes en todos los casos, salvo que una norma con rango de ley o norma de Derecho Comunitario Europeo establezca lo contrario. Quedan exceptuados de esta previsión los procedimientos de ejercicio del derecho de petición, a que se refiere el artículo 29 CE...». Se deduce del artículo reproducido, que el ejercicio del derecho de petición se sustancia como un procedimiento administrativo más, y que se asimila a una solicitud, lo cual es incompatible con la misma naturaleza del derecho de petición. Además, el propio artículo 31 de la LRJAP establece como interesado en el procedimiento administrativo a "quienes los promueven como titulares de derechos o intereses legitimos individuales o colectivos". Incluso en su apartado b), sigue manifestando que son también interesados en el procedimiento, "los que sin haber iniciado el procedimiento, tengan derechos que puedan resultar afectados por la decisión que en el mismo se adopte».

La defensa de un derecho o un interés legítimo, es la que diferencia a la solicitud de la petición. Si el ciudadano pretende la aplicación de cualquier norma del ordenamiento jurídico, está ejercitando una solicitud, porque persigue un interés regulado jurídicamente, y del que se entiende acreedor, y solicita un resultado que viene exigido por el derecho.

Como afirma Colom Pastor «en un caso, el ciudadano ocupa una posición relevante frente a los poderes públicos porque es titular de un derecho subjetivo o de un interés legítimo... en el otro, el ciudadano no goza de esa posición, no es titular de un derecho subjetivo o interés legítimo frente a los poderes públicos y en este caso los poderes públicos, valorando lo que es más oportuno para el interés general otorgarán o denegarán las peticiones» ${ }^{37}$.

También conviene establecer, que el Derecho Administrativo otorga en determinados casos, la posibilidad de ser parte en un procedimiento a través de la denominada acción pública, que tiene vigen- 
cia en la regulación sobre urbanismo ${ }^{38}$, $\operatorname{costas}^{39}$ o en lo relativo al patrimonio histórico ${ }^{40}$. Pero en todos estos casos, lo que se ejercita no es un derecho de petición, a pesar de que los participantes en estos procedimientos no defienden un derecho subjetivo o interés legítimo, y sí una pretensión fundada en derecho, que lo diferencia del derecho de petición.

\subsubsection{Petición y denuncia}

La denuncia es poner en conocimiento de una autoridad, la presunta comisión de un delito o falta. Procede y se regula ésta, tanto en el ámbito administrativo como en el penal, con objeto de que la autoridad competente inicie un procedimiento para la atribución de las responsabilidades y consecuencias, que el ordenamiento jurídico establece para aquél cuya imputación es constatable.

Quien formula la denuncia puede estar desprovisto de un derecho subjetivo o de un interés legítimo, lo que es parcialmente coincidente con el derecho de petición. Ahora bien, la denuncia tiene una pretensión concreta, la manifestada, que no coincide con el ámbito genérico del derecho de petición, lo que les diferencia.

\subsubsection{Petición y quejas al Defensor del Pueblo o figuras afines en las Comunidades Autónomas}

La queja viene regulada en el LRJAP, y puede interponerse contra defectos de tramitación en el procedimiento administrativo (art. 79.2 y 3). Para el mismo supuesto se contempla en el Reglamento de Procedimiento en las reclamaciones económico-administrativas (R. D. 391/1996, de 1 de marzo), en su artículo 73, y también en la Ley Reguladora de la Jurisdicción Contencioso-Administrativa (Ley 29/1998, de 13 de julio), en su artículo 40.4, cuando se funda en la indebida fijación de una cuantía.

En todos estos casos, es fácilmente diferenciable la queja del derecho de petición, dado que hay una pretensión jurídica. Por el con-

38 Artículo 304 de la Ley sobre Régimen del Suelo y Ordenación Urbana.

39 Artículo 109.1 de la Ley de Costas (Ley 22/1988).

40 Artículo 8.2 de la Ley del Patrimonio Histórico Español. 
trario, el concepto queja referido a la función del Defensor del Pueblo, plantea alguna dificultad añadida, además de que en la actualidad se identifica queja más con el escrito que se dirige a esta institución, que con los casos que hemos referido al inicio de este apartado.

Es constatable, que la creación de la figura del Defensor del Pueblo ha producido una minoración considerable del derecho de petición $y$ de este mismo derecho ejercitado ante el Parlamento. Pese a todo, no cabe identificar las quejas que se formulan ante esta institución con el derecho de petición. El elemento diferenciador es como en la mayoría de los casos anteriores la pretensión de defensa de intereses legítimos. El art. 10.1 de la Ley Orgánica del Defensor del Pueblo (en adelante LODP) establece que "podrá dirigirse al Defensor del Pueblo toda persona natural o jurídica que invoque un interés legítimo...».

Otra diferencia sustantiva con el derecho de petición viene constituida por el hecho de que el Defensor del Pueblo puede «iniciar o proseguir de oficio 0 a petición de parte, cualquier investigación...», circunstancia que no se da en el derecho de petición, en el que el poder público en ningún caso puede actuar de oficio.

También existen diferencias en el ejercicio de ambos derechos, dado que la petición no tiene plazo para ser ejercitada, por el contrario, el derecho de queja habrá de ejercitarse en el plazo máximo de un año, contado a partir del momento en que se tuviera conocimiento de los hechos que fundamentan la misma (art. 15 de la LODP).

Las restricciones en el ejercicio de las quejas, son mayores que en el derecho de petición, dado que el artículo 10.3 de la LODP establece que «no podrá presentar quejas ante el Defensor del Pueblo ninguna autoridad administrativa en asuntos de su competencian.

Por último, la reciente entrada en vigor de la Ley Orgánica 4/2001, ha venido a clarificar de forma definitiva el diferente uso de uno y otro derecho, de esta forma, su Disposición Adicional Segunda establece que uqueda excluida de la aplicación de esta ley el régimen de las quejas dirigidas al Defensor del Pueblo y a las instituciones autonómicas de naturaleza análoga, que se regirán por su legislación específica».

\subsection{Sujetos del Derecho}

No es un aspecto baladi el de la determinación de los sujetos, y de forma especial, la concreta extensión de los sujetos activos, sobre todo teniendo en cuenta que el artículo 29 de la Constitución españo- 
la utiliza el término "todos los españoles...", y por el contrario la Ley Orgánica 4/2001 reconoce el uso del derecho a «toda persona natural o jurídica...".

La polémica sobre la extensión del derecho de petición a los extranjeros no es novedosa. Se dio ya en el elaboración de la Constitución de 1869. El Diputado Palanca proponía su reconocimiento con carácter genérico, dado que es un derecho que ejerce el hombre «cualquiera que sea su edad, cualquiera que sea su estado, cualquiera que sea su naturalezan. Por el contrario, la postura que tuvo reflejo en la letra de la Constitución fue la del Diputado Ologoza, quien entendía que las "Cortes no están haciendo la ley de la naturaleza, las Cortes están haciendo una Constitución política» ${ }^{41}$.

Parecida circunstancia se dio en la elaboración de nuestra vigente Constitución. La Enmienda $n .^{\circ} 23$ al Proyecto de Constitución, formulada por el senador Martín-Retortillo, proponía una regulación del siguiente tenor: "queda garantizado el derecho de petición que se ejercerá con arreglo a lo que disponga la ley». En argumento de ello, afirma el senador que "tratándose de un derecho tan obvio, tan elemental, ¿por qué limitarlo e impedirlo a los extranjeros?». Continúa manifestando el senador que use admite lo que es más complicado; los recursos judiciales que los extranjeros en nuestra patria pueden utilizar sin género de duda $y$, en cambio, les quedaría excluido este derecho " ${ }^{42}$. La argumentación de Martín-Retortillo tuvo éxito, y fue aprobada la enmienda, viniendo a constituir el texto del artículo 29 aprobado por el Pleno del Senado. No obstante, el Dictamen de la Comisión Mixta, se decantó por la versión del Congreso, es decir, por la expresión «todos los españoles...».

La Ley 92/1960, de 22 de diciembre, también restringió el uso del derecho de petición a los españoles, en su artículo 1 se establece que "el derecho de petición es la facultad que corresponde a los españoles para dirigirse a los poderes públicos». En sintonía con estos contenidos jurídicos, y como hemos referenciado, la Constitución de 1978, en su artículo 29.1 reserva este derecho a los españoles. Nada aportará una interpretación extensiva del art. $13 \mathrm{CE}$, el cual en su apartado primero establece que "los extranjeros gozarán en España de las da, pág. 260.

41 Ambos fragmentos los referencia GARCIA EsCUDERO, J. M., en obra citapág. 1974. 
libertades públicas que garantiza el presenteTítulo en los términos que establezcan los tratados y la ley». En puridad, el artículo transcrito es una remisión a la legislación ordinaria, por lo cual habremos de acudir a ella. El artículo 4.1 de la Ley Orgánica 7/1985, de 1 de julio, sobre derechos y libertades de los extranjeros en España, reproduce parcialmente el art. $13 \mathrm{CE}$. Algo más significativo es el artículo 5.1, que establece la posibilidad de que los extranjeros gocen de derechos políticos a excepción de «los derechos de sufragio activo o pasivo, ni acceder al desempeño de cargos públicos", de lo que se deduce que gozan del resto de derechos, incluido el derecho de petición.

Algo más de luz aportará la vigente Ley Orgánica sobre derechos y libertades de los extranjeros en España (Ley Orgánica 8/2000, de 22 de diciembre), la cual a su vez modifica la Ley Orgánica 4/200, de 11 de enero. En su Exposición de Motivos se establece que "entre las modificaciones introducidas a este Título de la Ley destaca la preocupación en reconocer a los extranjeros la máxima cota de derechos y libertades». Esta pretensión se concreta en la Ley, de forma tal que el artículo 3.1, en su inciso final, establece que "como criterio interpretativo general, se entenderá que los extranjeros ejercitan los derechos que les reconoce esta Ley en condiciones de igualdad con los españoles». Habrá que deducir, tras lo expuesto, que los extranjeros gozan en España del derecho de petición, en igualdad de condiciones como se les reconoce a los nacionales. Así lo ha venido a corroborar la reciente Ley reguladora del derecho de petición (Ley Orgánica 4/2001), cuando establece en su artículo 1 que "toda persona natural o jurídica, prescindiendo de su nacionalidad, puede ejercitar el derecho de petición".

De esta forma, la Ley 4/2001 viene a desarrollar el artículo $29 \mathrm{CE}$, y a corregir las limitaciones ilógicas que se habían establecido, tanto por la propia Constitución, como por la legislación de desarrollo. La posibilidad de ejercitar el derecho de petición por toda persona, encuadra de forma más racional con la propia naturaleza del derecho, que no es otra que la de ser cauce de expresión del ciudadano y como medio de participación de éste en la mejora de las tareas públicas.

Por último, no comentamos la atribución de este derecho a las personas jurídicas, dado que no plantea las dudas que pueden surgir en la atribución de otros derechos fundamentalmente, los que denominamos derechos de la personalidad. Rige pues al respecto del derecho de petición en ellas, el principio de que podrán ser titulares de los derechos que sean compatibles con su naturaleza jurídica, circunstancia que se da en cuanto al derecho de petición. 


\subsection{La limitación a los miembros de las Fuerzas Armadas}

Hasta fechas recientes tres eran los grupos que tenían limitado el ejercicio del derecho de petición, los funcionarios, los presos y los miembros de las Fuerzas Armadas o cuerpos sometidos a disciplina militar.

Respecto de los primeros, el artículo 21 en su párrafo segundo, del Fuero de los Españoles fue reproducido de forma casi literal por el artículo 70.3 de la Ley de Procedimiento Administrativo, limitando a los funcionarios su ejercicio del derecho de petición. También estableció limitaciones el artículo 39.4 de la Ley de Régimen Jurídico de la Administración del Estado. La Ley 92/1960 reguladora del derecho de petición, remitía a los normas que regulaban a los funcionarios, estableciendo su artículo 4 que "sólo podrán ejercitar este derecho de acuerdo con las disposiciones por que se rijan".

Tanto la Ley de Procedimiento, como la Ley de Régimen Jurídico, fueron expresamente derogadas por la LRJAE, en su Disposición Derogatoria 2 a) y b). Por lo que respecta a la Ley 92/1960, además de haber sido derogada expresamente por la Ley Orgánica 4/2001 (Disposición Derogatoria única) la única excepción que recoge es la del apartado segundo del artículo 1, es decir, «los miembros de las fuerzas o institutos armados o de los cuerpos sometidos a disciplina militarn, a los que remite en su ejercicio a la legislación específica. Deducimos de lo expuesto la desaparición de la prohibición de ejercer el derecho de petición a los funcionarios.

El otro grupo de ciudadanos que tradicionalmente ha visto limitado su derecho de petición, ha sido el de los condenados a pena de prisión. Rige para ellos el artículo 25.2 de la Constitución, que establece que "el condenado a pena de prisión que estuviere cumpliendo la misma gozará de los derechos fundamentales de este capítulo, a excepción de los que se vean expresamente limitados por el contenido del fallo condenatorio, el sentido de la pena y la Ley Penitenciaria". El Tribunal Supremo ha entendido que uel derecho de petición no es una facultad de que se hallen privados los reclusos, y tanto la Ley General Penitenciaria (1/1979, de 26 de septiembre), como el Reglamento Penitenciario (Real Decreto 192/1996, de 9 de febrero) contemplan de forma expresa el ejercicio del derecho de petición de los internos. Conviene destacar que el derecho reconocido en estas normas es singular, dado que se reconoce en función de que son presos. Así el artículo 50.1 de la Ley General Penitenciaria establece que "los internos tienen derecho a formular peticiones y quejas relativas a su tratamiento $o$ al régimen del establecimiento ante el Director o persona que le representen. Pero a este derecho se suma el genérico y constitucional derecho de petición. 
En definitiva, y como reconoce Álvarez Carreño «la legislación penitenciaria no establece ningún tipo de restricción material al ejercicio del derecho de petición por los internos en centros penitenciarios, a pesar de la defectuosa, o mejor, engañosa redacción de los diversos preceptos que a aquél se dedican " ${ }^{43}$. Pero también es cierto, que la Ley Orgánica 4/2001, singulariza las peticiones realizadas por los internos en instituciones penitenciarias, dado que la Disposición Adicional Tercera establece que "las peticiones formuladas por los internos en el ámbito regulado por la Ley Orgánica 1/1979, de 26 de septiembre, se ajustarán a los dispuesto en la misma».

Analizados estos dos grupos de ciudadanos que en principio pudiera parecer que tienen alguna limitación en el ejercicio del derecho de petición, y comprobado que no es esta la circunstancia, analizamos el tercer grupo, los miembros de las fuerzas o institutos armados sometidos a disciplina militar, que sí constituyen un grupo en el que opera la limitación al ejercicio del derecho que estudiamos.

Como hemos visto, la Ley Orgánica 4/2001, remite el derecho de petición de este grupo de ciudadanos a su legislación específica. La Ley Orgánica 2/1986, de 13 de marzo, de Fuerzas y Cuerpos de Seguridad, en su artículo 15.2, prohíbe hacer peticiones colectivas, si bien permite hacerlas de forma individual en los términos establecidos en su legislación específica.

Conviene de forma previa esclarecer qué se entiende por miembros de las Fuerzas Armadas. A este respecto habrá que excluir al personal civil que preste servicios en ellas, así como otros cuerpos que no están sometidos a disciplina militar, como son la policía nacional, las autonómicas o la policía municipal. Por el contrario si habrá de incluirse a la Guardia Civil44. También conviene delimitar que la prohibición opera únicamente al respecto de peticiones relacionadas con sus cometidos, y que en ningún caso se entiende que pueda extenderse a su actividad como ciudadanos ${ }^{45}$.

43 Álvarez Carreño, S. M.: El derecho de petición, Comares, Granada, 1999, pág. 621. Estado.

44 Artículo 13.1 de la Ley Orgánica de Fuerzas y Cuerpos de Seguridad del

45 Así venía establecido en el art. 1 del Decreto de 18 de enero de 1962, el cual establecía que "el ejercicio del derecho de petición por los miembros de las Fuerzas e Institutos Armados habrá de someterse a las normas peculiares que establece la presente disposición, siempre que sus peticiones estén en el ámbito de la 
De esta forma, la regulación específica del derecho de petición para los militares, viene establecida en el artículo 199 de las Reales Ordenanzas, los cuales establecen que «el militar sólo podrá ejercer el derecho de petición individualmente, en los casos y con las formalidades que prevenga la ley». Estas las concreta el artículo 203 del cuerpo normativo que venimos citando, según el cual, "cualquier militar podrá dirigir propuestas a sus superiores haciéndolo individualmente y por conducto regular. Cuando sea autorizado para ello podrá recabar el parecer de sus compañeros para la consideración de posibles sugerencias que habrán de ser presentadas por el más caracterizado». Al respecto de este artículo se ha pronunciado el Tribunal Constitucional a través del Auto $375 / 1983$, de 30 de julio, el cual en su fundamento jurídico segundo, se establece que " ha de entenderse conforme a la Constitución el contenido del artículo 203 de las Reales Ordenanzas, sometiendo las peticiones de los militares a sus superiores a un régimen restrictivo...».

En cuanto al contenido de las peticiones, también reconocen límites las Reales Ordenanzas, de esta forma, el artículo 205 establece que «el militar profesional podrá dirigirse al órgano superior encargado de la gestión y coordinación de los asuntos sociales y de personal de las Fuerzas Armadas para plantear asuntos referidos a su profesión, siempre que no estén directamente relacionados con la justicia y disciplina, con la orgánica y medios de equipo y material, ni con la instrucción y formación militar».

De forma correlativa a las limitaciones del contenido de las peticiones y de la forma de llevarlas a efecto, la legislación específica establece sanciones. Así, el artículo 8.12 de la Ley Orgánica 12/1985 de Régimen Disciplinario de las Fuerzas Armadas, considera falta leve "hacer reclamaciones o peticiones en forma o términos irrespetuosos o prescindiendo del conducto reglamentarion.

Por su parte, el artículo 9.15 del mismo texto, considera falta grave "hacer reclamaciones, peticiones o manifestaciones contrarias a la disciplina o basadas en aseveraciones falsas; realizadas a través de los medios de comunicación social o formuladas con carácter colectivon.

Ley reguladora y se refieran a materia de la competencia de los ministerios o autoridades militares, 0 que de algún modo afecte a estos 0 a los ejércitos.

Fuera de estos casos antedichos, las peticiones de este personal se atendrán únicamente a las prescripciones de la Ley reguladora». 
Por su parte el Código Penal Militar ${ }^{46}$ tipifica como tipos privilegiados al delito de sedición militar, "las reclamaciones o peticiones colectivas en tumulto, con las armas en la mano, o con publicidad" (art. 92.1), y las demás "peticiones o reclamaciones colectivas, así como las reuniones clandestinas para ocuparse de asuntos del servicion (art. 92.2).

Pese a todo, y partiendo de la necesaria limitación del ejercicio del derecho de petición, puede concluirse que realiza una función de poner en conocimiento de los superiores aspectos que afectan a los militares. Un ejemplo de la virtualidad de este derecho dentro de las fuerzas armadas nos lo pone de manifiesto Vigier Glaría quien analiza la actividad realizada por la oficina del derecho de petición en la Casa del Rey ${ }^{47}$.

\section{REOUISITOS PROCEDIMENTALES EN EL DERECHO DE PETICIÓN}

Varios son los aspectos a contemplar desde la perspectiva procesal, y todos son importantes, dado que la virtualidad del derecho que estudiamos se sustenta en gran medida en el cumplimiento, tanto por parte del peticionario, como del destinatario.

\subsection{Contenido y requisitos formales de la petición}

Como hemos venido manifestando, ninguna norma limita la materia de la petición, de forma tal que podrá incorporar una sugerencia, una iniciativa, una información o expresar súplicas, además del petitum. Por el contrario, sí existen limitaciones formales, así la Ley Orgánica 4/2001 establece que habrá de formularse la petición por escrito, y podrá presentarse ante cualquier registro o dependencia administrativa, en la forma que establece la LRJA (artículo 6). Por su parte el artículo 4 de la LO 4/2001 establece que también podrá presentarse la petición a través de medios electrónicos, siempre que se permita acreditar su autenticidad, $y$ siempre que incluya la identidad

46 Ley Orgánica 13/1985, de 9 de diciembre.

47 VIGIER Glaría, L. F:: «El derecho de petición: algo más que un derecho inofensivo", Revista Española de Derecho Militar, n. ${ }^{\circ} 55$ de 1990, págs. 151 y ss. 
del peticionario, la nacionalidad, el lugar y medio elegido para la practica de la notificación, el objeto y el destinatario de la petición. Es importante referir también al respecto de los datos, que se establece la posibilidad, si así lo exigen los peticionarios, de la confidencialidad de los mismos (artículo 4.4). También establece la Ley, que el escrito podrá formularse en cualquiera de las lenguas oficiales y se tiene derecho a "obtener respuesta en la lengua de su elección", siempre que esta sea cooficial en el ámbito territorial de la Comunidad Autónoma (artículo 5). El apartado $3 .^{\circ}$ del mismo artículo establece la obligación de ula institución, administración u organismo instructor de traducir al castellano los documentos, expedientes o partes de los mismos que deban surtir efectos fuera del territorio de la Comunidad Autónoma y los documentos dirigidos a los interesados que así lo soliciten expresamente".

Conviene también recordar, que la única limitación que establece la Ley respecto del contenido es la contemplada en el artículo 3 , en su párrafo $22^{\circ}$, en virtud del cual «no son objeto de este derecho aquellas solicitudes, quejas o sugerencias para cuya satisfacción el ordenamiento jurídico establezca un procedimiento específico distinto al regulado en la presente Ley".

\subsection{Tramitación de las peticiones}

Una vez presentado el escrito, la administración, institución pública o autoridad, emitirá un acuse de recibo, en virtud del cual comunica al interesado en un plazo de diez dias la recepción de aquél.

Una vez que la petición está en poder de la institución o autoridad, ésta debe verificar que aquélla es adecuada con arreglo a los requisitos que establece la Ley Orgánica 4/2001, para lo que podrá recabar asesoramiento, así como realizar las diligencias o comprobaciones que estime pertinentes. En el supuesto de que la petición adoleciera de algún defecto formal o material, se requerirá al peticionario para que lo subsane en un plazo de 15 días. En el supuesto de que no realice la subsanación, se le tendrá por desistido de su petición. En este caso habrá de comunicarse esta circunstancia al peticionario, exponiendo la causa de la misma (artículo 7.2). Como resultado de todas estas averiguaciones la administración o autoridad habrá de resolver, admitiendo o inadmitiendo a trámite la petición.

El destinatario de la petición, en virtud del artículo 7.3, puede solicitar del peticionario «la aportación de aquellos datos o documentos 
complementarios que obren en su poder o cuya obtención esté a su alcance $y$ que resulten estrictamente imprescindibles para tramitar la petición». En el supuesto de que estos no fueran aportados, no es causa de inadmisibilidad de la petición.

La Ley 92/1960 establecia en su artículo 7.2 que «si la autoridad ante la que se deduzca una petición se estimare incompetente para resolverla, la remitirá a la que considere competente y comunicará el haberlo hecho al peticionario". La Ley $4 / 2001$, reitera este contenido en el artículo 10.2, pero añade que habrá de hacerlo en el plazo de diez días. En este supuesto, el computo del plazo para contestar, empieza a correr a partir del día siguiente en el que la autoridad competente recibe la petición.

Una vez que la petición obra en poder de la autoridad, administración o institución competente se abren dos posibilidades, la admisión o la inadmisión. En éste último caso, se da por finalizada la petición. Lo que obliga a notificarlo al peticionario en un plazo máximo de cuarenta y cinco días hábiles, contados desde el día siguiente a la presentación. La declaración de inadmisibilidad de la misma, habrá de ser en todo caso motivada (art. 9.1).

En el supuesto de que la petición sea inadmitida porque el ordenamiento jurídico establece un procedimiento específico para la satisfacción del contenido de la petición, la administración, institución o autoridad que inadmita la petición, habrá que comunicarle al peticionario de forma expresa qué procedimiento ha de utilizar, asi como la autoridad o administración competente para recibirla.

En todo caso, si en el plazo de cuarenta y cinco días hábiles desde que se presentó la petición no se ha recibido contestación, "se entenderá que la petición ha sido admitida a trámiten.

\subsection{Obligaciones del destinatario de la petición admitida a trámite}

Cuando analizamos el contenido esencial del derecho de petición, llegamos a la conclusión de que formaba parte de aquél la obligación del destinatario de contestar motivadamente la petición, y así lo recoge la Ley $4 / 2001$ en su artículo 11.1 cuando establece que "una vez admitida a trámite la petición, la autoridad u órgano competente vendrá obligado a contestar y a notificar la contestación en el plazo máximo de tres meses a contar desde la fecha de presentación". 
Se deduce del contenido de la Ley 4/2001, que habrán de ser admitidas a trámite, aquellas peticiones que se estimen fundadas, por ello establece como primera consecuencia que "vendrá obligado a atenderla y a adoptar las medidas que estime oportunas a fin de lograr su plena efectividad, incluyendo en su caso, el impulso de los procedimientos necesarios para adoptar una disposición de carácter general” (art. 11.2). También obliga la norma, a que la contestación recoja, al menos, "los términos en los que la petición ha sido tomada en consideración", a la vez que habrá de incorporar "las razones y motivos por los que se acuerda acceder a la petición o no hacerlon (art. 11.3).

Incluso la autoridad, institución o administración que entiende razonada la petición, puede ir más allá, adoptando acuerdos o tomando medidas tendentes a su ejecución. En este supuesto, habrá de adjuntarlo a la resolución.

Con objeto de dar publicidad a la resolución del derecho de petición, también posibilita la Ley 4/2001, en su artículo 11.4, a publicar la resolución, en "el diario oficial que corresponda".

En definitiva el derecho de petición requiere de ejecutividad y efectividad por parte del poder público. De lo contrario, sería una forma de vaciar de contenido el derecho, o en todo caso habría que ratificar la palabras de Laband, para quien el derecho de petición «es tan natural y tan vacío como escribir cartas o entonar canciones» ${ }^{48}$. Y se constituye por tanto, y en palabras de Garrido Falla, en la via para "plantear a la Administración lo que no se puede obtener por vía de recurso" 49 .

De esta forma el peticionario no sólo pone en funcionamiento su derecho subjetivo, sino que la petición genera obligaciones al destinatario. La de contestar, y hacerlo motivadamente. Pero además, y como acertadamente nos recuerda Colom Pastor, el peticionario «tiene derecho a que el contenido de la resolución no infrinja, conculque o vulnere el principio de igualdad o el de interdicción de la arbitrariedad de los poderes públicos» ${ }^{50}$. El que la petición no pueda tener en ningún caso un contenido jurídico para el que el ordenamiento jurídico establece un procedimiento específico, no es óbice para que la resolución esté fundamentada y sea ajustada a derecho.

48 Cita recogida de la obra de Pérez Serrano, N.: La Constitución Españo1a. Antecedentes, Texto y Comentarios, Madrid, 1932, pág. 159.

49 GarRIDo Falla, F.: Comentarios a la Constitución, Madrid, 1985, pág. 593.

50 Obra citada, pág. 87. 
Por último, conviene recordar como obligación de la autoridad u órgano competente para resolver la petición, que el artículo 11.5 de la Ley Orgánica 4/2001 obliga a que anualmente se confeccione uuna memoria de actividades derivadas de las peticiones".

\subsection{La protección jurisdiccional del derecho de petición}

Si hubiéramos de valorar la importancia de los derechos, tarea no exenta de dificultad, es probable que el derecho de petición no estuviera entre los primeros. Por ello parece lógica la ubicación en la Constitución, donde se le reconoce como último derecho fundamental. Pero si hubiéramos de clasificar al derecho de petición por los medios que el ordenamiento jurídico ofrece para su ejercicio efectivo, no cabe la menor duda, de que el derecho que estudiamos se encontraría entre los más garantizados, como así ocurre.

En el derecho de petición se superponen la protección constitucional, la que otorga su desarrollo legislativo, y por último, la que le establece toda la legislación administrativa. Analizamos por separado cada una de ellas.

1. ${ }^{\circ}$ El artículo 53.1 de la Constitución establece para todos los derechos incluidos en el Capítulo II delTítulo I, «la vinculación a todos los poderes públicos». Pero el apartado segundo del artículo citado va más allá en lo relativo a los derechos de la Sección primera del mismo Capítulo y Título citados, estableciendo que puede acudirse a «losTribunales ordinarios para un procedimiento basado en los principios de preferencia y sumariedad». Es el denominado recurso de amparo ordinario. Pero el citado artículo en el inciso final, le otorga la máxima protección que nuestra Constitución puede dar a un derecho, que no es otra que el recurso de amparo ante el Tribunal Constitucional.

2. Por su parte, la Ley Orgánica 4/2001, en su artículo 12, abre la vía contencioso-administrativa, y de forma concreta en lo relativo a las protección jurisdiccional de los derechos fundamentales de la persona (arts. 114 y siguientes de la Ley 29/1988, de 13 de julio, Reguladora de la Jurisdicción Contenciosa-Administrativa) en caso de que se den los siguientes supuestos:

«a) la declaración de inadmisibilidad de la petición; 
b) la omisión de la obligación de contestar en el plazo establecido;

c) la ausencia en la contestación de los requisitos mínimos establecidos en el artículo anterior".

3. Por último, el peticionario, admitida o inadmitida la petición, una vez que se le acusa recibo de haber formulado la petición, tiene abierta la vía administrativa, y puede en todo momento reclamar a la administración, institución o autoridad, el cumplimiento de la normativa vigente, y en todo caso, como establece el artículo 42 de la Ley 30/1992, de 26 de noviembre, "la Administración está obligada a dictar resolución expresa en todos los procedimientos y a notificarla cualquiera que sea la forma de iniciación".

\section{EL DERECHO DE PETICIÓN EN OTROS ORDENAMIENTOS JURÍDICOSY EN LA UNIÓN EUROPEA}

Viene siendo habitual en los estudios de Derecho Constitucional, y de forma especial en el acercamiento científico a los derechos fundamentales, tener siempre una perspectiva compara. Ello ayuda de forma significativa al entendimiento de los mismos, a la vez que produce una necesaria comparación en las regulaciones. De ambas se obtienen resultados no poco favorables. Es curioso observar como tras la generalización del reconocimiento constitucional del derecho de petición, éste opera de forma y con contenidos dispares. Quizás sea debido ello a la versatilidad del derecho, pero también lo es a que los distintos ordenamientos jurídicos lo van perfilando con arreglo a unas necesidades $y$ contexto diferente. Por estas razones creo muy conveniente realizar un estudio, aunque sea somero, del derecho de petición en los ordenamientos jurídicos de nuestro entorno (Reino Unido, Estados Unidos, Alemania, Francia e Italia), así como en el ordenamiento supranacional que nos es de aplicación, es decir, el de la Unión Europea.

\subsection{Reino Unido}

Como afirma Pérez Serrano, este derecho ha tenido históricamente "una inmensa importancia; la historia constitucional inglesa es obra, en buena parte, del derecho de petición, porque la condensación 
de opiniones y el asenso de voluntades ha servido de acicate poderoso para las más varias reformas ${ }^{51}$.

También conviene constatar, que no son pocas las similitudes en el origen del derecho de petición del Reino Unido con España. Habiendo sido aquél un Estado monárquico hasta la actualidad, era competencia del Rey impartir justicia, si bien la delegaba en el sheriff de cada condado, quedando al monarca la instancia suprema (Curia Regis).

El derecho británico tiene un reconocimiento expreso del derecho de petición por primera vez en la Carta Magna de Juan sin Tierra de 1215, dado que establece en su artículo 38 que "Nulli vendemus, nulli negabimus aut differemus, rectum vel iustitiam ${ }^{52}$. Esta obligación no se pierde con posterioridad, es más Enrique IV asigna dos días por semana para atender las peticiones de sus súbditos ${ }^{53}$.

Con posterioridad, y como nos recuerda García Cuadrado, «el primer dato interesante que nos aporta la experiencia inglesa en esta materia es la asunción por parte del Parlamento desde sus orígenes del derecho de presentar peticiones al rey». Estas se constatan desde 1305, y como afirma Potter ${ }^{54}$, estaban fundadas en supuestos agravios a colectividades. También puede afirmarse, que como las peticiones necesitaban de un desarrollo normativo que posibilitara su ejecución, desde el reinado de Enrique VI, se establece la costumbre de que las peticiones adoptaban la forma de proposición de ley, pudiendo el Rey aceptarlas o rechazarlas en su conjunto, y no pudiendo en ningún caso introducirle modificaciones.

Con la traslación del poder legislativo del monarca al Parlamento, se remiten a este, y de forma singular a la Cámara de los Comunes, aquellas peticiones que tienen un carácter eminentemente legislativo, conservando el Rey el derecho de las peticiones que tienen un carácter graciable.

51 Pérez Serrano, N.: Tratado de Derecho Político, Civitas, 2." ed., 7." reimpresión, Madrid, 1997, pág. 670.

52 «A nadie venderemos, negaremos ni retrasaremos su derecho o a la justicia». Traducción obtenida de la obra de Álvarez Vélez, M." I., y Alcón Yustas, M." F: Las Constituciones de los quince Estados de la Unión Europea, Dykinson, Madrid, 1996, pág. 588.

53 Así lo referencia KELLY, A. H.: "Right of petition», en la Encyclopedia Britannica, Londres, 1971, vol. XVII, pág. 748. pág. 138.

54 POTTER, H.: Historical introduction to English Law, 4. ${ }^{a}$ ed., Londres, 1958, 
La aprobación de la Petition of Right de 1628 supuso una reactualización del derecho de petición, corregido parcialmente en 1661, fecha en la que se prohíben las peticiones tumultuosas. También el Bill of Right de 1689 reconoce en su artículo 5 el derecho de petición de una forma precisa, cuando establece que "es un derecho de los súbditos presentar peticiones al rey, siendo ilegal toda prisión o procesamiento de los peticionarios".

Al contrario de lo que ocurrirá en el ordenamiento jurídico de Estados Unidos, en el Reino Unido, el derecho que estudiamos, no irá más allá en su reconocimiento, ni tampoco en su uso. Su vigencia es escasa, sin intencionalidad política en su utilización, y tampoco puede decirse que sea una forma de ejercitar la genérica libertad de expresión. Su uso colectivo es prácticamente inexistente, y ha quedado reducido a mero mecanismo para que la Corona realice actos graciables.

\subsection{Estados Unidos}

Es recurso común en los historiadores norteamericanos afirmar, que al contrario de lo que ocurría en las colonias españolas o francesas, los colonizados de Norteamérica tenían los mismos derechos que los ciudadanos de la metrópoli. De esta forma el derecho de petición pasó a las Cartas otorgadas. Así ocurre con la de Virginia de 1606, la de Massachussets de 162955. Por el contrario, el más significativo texto relativo a derechos de la época posterior, la Declaración de Derechos de Virginia de 1776, no hace referencia alguna al derecho de petición.

La Declaración de Independencia aprobada por el Congreso de Estados Unidos el cuatro de julio de 1776, en la que se enumeran las causas que justifican la independencia de Estados Unidos del Reino Unido, argumenta entre ellas la omisión de las peticiones coloniales ${ }^{56}$. De la misma forma, la mayoría de las declaraciones de derechos de los

55 Ésta recoge de forma expresa el «freedom of speech and petition at public meetings".

56 Así lo recoge también SMITH, para quien ala disolución de los cuerpos legislativos de las colonias por su propensión a ejercer el derecho de petición para la reparación de los agravios y el hecho de que el desprecio inglés por dichas peticiones se convirtiera por sí mismo en un agravio, demuestran que el derecho de petición fue una de las causas precipitadoras de la Declaración de Independencia». SMITH, D. L.: The right to petition for redress of grievances: constitutional development and interpretations, Texas, 1971, pág. 114. 
Estados, recogen el derecho de petición ${ }^{57}$. En resumen, y como afirma Spanbauer, "todas las colonias, incluso aquellas que no otorgaban una protección explícita a su ejercicio, garantizaban el derecho de petición como el método por el cual los ciudadanos participaban en la acción de gobierno, permitiéndoles expresar sus puntos de vista» ${ }^{58}$.

Pese a todo, como ocurrió con otros muchos derechos, el derecho de petición no formó parte de la Constitución de Estados Unidos de 1787. Pero no se prolongó mucho esta ausencia, dado que con la aprobación de las primeras enmiendas en 1791, se introdujo en la Primera el derecho de petición.

A pesar de su reconocimiento y uso, no existe aún en el derecho norteamericano una concreta limitación de su significado y contenido. Esta se producirá con el crecimiento del movimiento antiesclavista. De esta forma, se utiliza el derecho de petición para la derogación de la Ley Federal sobre el comercio de esclavos de $1794^{59}$. También fue partícipe el derecho de petición de las controversias políticas sobre extranjería, sedición y segregación. Recurrir a él, fue uno de los mecanismos de participación ciudadana en la vida politica durante todo el siglo XIX y principios del $X X$.

A partir de mediados del siglo $X X$ se produce una significativa modificación en el ejercicio y en el concepto del derecho, de tal forma que se interpretarán de forma conjunta los tres derechos de la Primera Enmienda. Incluso el Tribunal Supremo no ha definido hasta la actualidad con precisión el derecho de petición, y se ha resistido sistemáticamente a afirmar o negar que abarque un único tipo de actividades. De ésta forma en Estados Unidos los derechos de libertad de expresión, asociación y petición están fuertemente entrelazados, sobre todo cuando su ejercicio tiene carácter político.

57 La Declaración de Pensylvania, La Declaración de Delaware y de Maryland, todas de 1776. La Declaración de Vermont de 1777, la de Massachussets de 1779, y la de New Hampshire de 1783, entre otras.

58 SPANBAUER, J. M.: «The first amendment right to petition government for a redress of grievances: cut from a different cloth". Hastings Constitutional Law. Quarterly, vol. 21, 1993, pág. 28.

59 Hasta tal punto se usó el derecho de petición con esta finalidad, que el Congreso de Estados Unidos aprobó el 8 de febrero de 1836 la siguiente Resolución: «Todas las peticiones, memoriales, proposiciones o documentos relativos a cualquier forma o en cualquier punto al tema de la esclavitud o al de la abolición de la misma serán rechazadas sin ser impresas ni remitidas, y no se realizará ningún tipo de actividad e relación a las mismas". 
Pese a todo lo manifestado, a partir de los años 60 , la conocida como doctrina Noerr-Pennington, elaborada por la Corte Suprema, da al derecho de petición una vertiente económica o comercial. Así, se encuentre protegido por la Primera Enmienda de la Constitución, el coordinarse con otros con la finalidad de influir en las decisiones de los órganos que integran el poder público. La citada doctrina presenta dos grandes deficiencias en el ejercicio del derecho de petición. La primera y más relevante es que la doctrina establece una inmunidad para el ejercicio del derecho de petición aun cuando se pretenda la consecución de una actuación ilegítima por parte de los poderes públicos. La segunda, es que otorga inmunidad aunque se causen daños innecesarios al principio de libre competencia económica.

Pese a esta vertiente tan mercantilista del derecho de petición, no puede olvidarse que éste derecho goza en Estados Unidos de un considerable uso, a la vez que está dotado de los mecanismos jurisdiccionales adecuados para su efectividad.

\subsection{Alemania}

El derecho de petición en Alemania es de origen tardío, a pesar de que existe ya en la Edad Media en los estamentos y sus asambleas (Ständen y Ständekammern), no se generaliza hasta el Estado Liberal. También en Alemania la evolución del estado feudal hacia las monarquías absolutas constituye una cierta institucionalización del derecho que estudiamos ${ }^{60} \mathrm{como}$ afirma Álvarez Carreño «no puede, sin embargo, hablarse todavía de un derecho de petición en sentido moderno, puesto que la capacidad jurídica para el envio de quejas $\gamma$ peticiones dependía del estamento feudal del que formara parte el peticionario, de tal forma que era el órgano de representación estamental, al que correspondía el ejercicio del derecho, sin que, siquiera, se garantizase la obligación de éstos de transmitir la petición al órgano competente para resolverla" ${ }^{61}$.

Los primeros textos constitucionales tampoco recogen el derecho de petición. Cabe excepcionar de éstas la Constitución de Baviera de 1818, que si bien no reconoce un derecho de petición propiamen-

60 La Carta del Principado de Sajonia de 1728 establece un procedimiento para la tramitación de peticiones a la vez que un plazo para su resolución

61 Obra citada, pág. 106. 
te, se le denomina queja, si es un precursor de lo que hoy conocemos por amparo constitucional. La constitución belga de 1831 ejerce una notable influencia en el constitucionalismo alemán, que tiene su ratificación en la Constitución prusiana de 1848, que en su artículo 30 establece que «se reconoce el derecho de petición de todos los prusianos. Las peticiones en nombre colectivo sólo se permiten a las Autoridades y Corporaciones». Un año después la Constitución del Imperio alemán incorpora la primera declaración de derechos de la historia constitucional alemana, reconociendo a "todos los alemanes... el derecho de dirigirse por escrito con peticiones o quejas a las autoridades, a los órganos estatales..... La Constitución imperial de 1871 también reconoce en su artículo 23 el derecho de petición. La Constitución de Weimar dedica su artículo 126 al derecho de petición y al derecho de queja. Se incorpora aqui la exigencia de un necesario actuar del poder público, a la vez que se requiere que la petición incluya una solicitud amparada por la Constitución o por las Leyes.

La vigente Constitución alemana reconoce en su artículo 17 que "todos tienen el derecho de dirigir por escrito, individual o colectivamente, sus peticiones o quejas a los órganos competentes o la representación populan. Lo primero que conviene destacar de este reconocimiento constitucional es la similitud semántica y material del artículo 29 de nuestra vigente coristitución con la Ley Fundamental, si bien es cierto que presenta también algunas diferencias. Quizás la más llamativa sea la configuración doctrinal y jurisprudencial de su interpretación negativa. Así el derecho de petición en Alemania se entiende como una libertad frente a la injerencia de los poderes públicos, 0 lo que es lo mismo, tiene como fin impedir que el poder público ponga obstáculos al ejercicio de las peticiones. Incluso, puede ejercitarse la petición en Alemania, independientemente de que se tenga un interés legítimo y directo en lo que es objeto de la petición. De esta forma puede usarse este derecho en defensa de intereses de terceros, $o$ del interés general. En todo caso, nunca podrá tener la petición una pretensión reconocida por el ordenamiento jurídico, ya que como ha establecido el Tribunal Constitucional Federal, se excluyen del derecho de petición todos los actos que constituyen condiciones procesales para la iniciación de procedimientos jurisdiccionales o administrativos.

También en el derecho alemán, la petición lleva implícita una necesaria actuación de los poderes públicos a los que se dirige, y así lo ha establecido el Tribunal Constitucional Federal, para quien el articulo 17 de la Ley Fundamental obliga a que utodas las peticiones legitimas deben ser respondidas, y esta respuesta no pude limitarse a una simple constatación de su recibimiento por el órgano destinatario, sino 
que de la misma deben desprenderse su conocimiento y la forma de su resolución" ${ }^{62}$. Ahora bien, ello no obliga a contestar motivadamente las peticiones, ya que a juicio delTribunal, la obligación constitucional no alcanza a tanto.

Parece clara la tendencia doctrinal alemana a ver en el derecho de petición más que una forma de iniciar el procedimiento administrativo, como ocurrió en España con la recientemente derogada Ley 92/1960, un mecanismo para suplir las carencias constitucionales de sistemas de participación democrática directa, aspecto éste que conviene analizar.

La desgraciada experiencia en cuanto a las formas de participación directa de la Constitución de Weimar, hizo de la Ley Fundamental un texto prácticamente sin reconocimiento de estas fórmulas de participación democrática. Por ello, la convulsión social de los años sesenta, se canalizó principalmente a través del derecho de petición. Es necesario recordar que el artículo 17 de la Ley Fundamental reconoce tanto las peticiones individuales como colectivas, y estas se vienen interpretando como una forma constitucionalmente garantizada de participación política directa de los ciudadanos en la formación de la voluntad del Estado.

Por lo que respecta al ámbito de aplicación personal del derecho de petición en Alemania, conviene recordar que al contrario de nuestra Constitución de 1978, la Ley Fundamental no restringe su uso a los nacionales, sino que el reconocimiento es genérico. No obstante, conviene recordar que podrán ejercer este derecho los extranjeros residentes en el territorio nacional. Se les niega, por el contrario y lógicamente, el derecho, a las personas de derecho público ${ }^{63}$, y no plantea problemas el reconocimiento del derecho de petición a las personas jurídicas, si bien como recoge Álvarez Carreño, se les exige a las personas jurídicas extranjeras "que tengan, por lo menos, un punto de conexión con el Estado alemán que les haga acreedores de la función de integración que el artículo 17 de la Constitución alemana representa en la relación entre Sociedad y el Estado" ${ }^{64}$.

62 Sentencia del Tribunal Constitucional Federal de 22 de abril de 1953.

63 Pese a la rotundidad de la manifestación, conviene recordar que el Tribunal Constitucional Federal ha reconocido este derecho forma de expresa a las Universidades, y de forma concreta en lo relativo a la libertad de cátedra, y a los entes públicos de comunicación social, en relación con el derecho a la libertad de expresión.

64 Obra citada, pág. 161. 
Otra singularidad en cuanto a los sujetos activos del derecho de petición, viene constituida por la limitación a los militares. Esta, al contrario que en el ordenamiento jurídico español, no es genérica, sino parcial, de esta forma, el artículo 17 a) de la Constitución establece que se limita el derecho de petición colectivo, pero no el individual ${ }^{65}$.

Nos queda por último, analizar en el ordenamiento jurídico alemán la protección jurisdiccional que se le dispensa al derecho de petición. Esta, como no podría ser de otra forma, dado el tratamiento constitucional que tiene el derecho que estudiamos, es la máxima que reconoce la Ley Fundamental. Su artículo 19 posibilita, en el supuesto de ser lesionados derechos por poderes públicos, acudir tanto a la vía parlamentaria como a la administrativa. No obstante, el procedimiento del derecho de petición se sustancia en vía contencioso-administrativa. El único requisito establecido por esta normativa es que el objeto de una petición, o cuestión litigiosa, no sea una cuestión de carácter constitucional. Esta viene determinada por la relación que une al peticionario con el órgano público al que se dirija.

\subsection{Francia}

No ha sido el derecho de petición en Francia un derecho extensamente reconocido, ni utilizado. Si bien existe en la Edad Media, no tuvo una generalización como la que hemos visto en España. La única constancia con valor jurídico hay que referirla a los Cuadernos de quejas que el Tercer Estado dirigió a Luis XVI en 1789. En esta ocasión y como afirma Fairén Guillén ${ }^{66}$, el derecho de petición «fue un instrumento político, puesto que la negativa real a aprobar algunos de los contenidos de los Cuadernos de peticiones, junto con la negativa del Tercer Estado a deliberar en un solo cuerpo con la nobleza, desencadenó la constitución de la Asamblea Nacional, y con ello se puso en marcha la Revolución Francesa». Pero curiosamente, la Declaración de Derechos del Hombre y del Ciudadano de 1789, no recogía el derecho de petición. Pese a esta circunstancia el derecho se ejercía. Incluso cualquier ciudadano podia redactar una petición y hacerla firmar por otros. A comienzos de la Revolución este derecho dio origen a innumerables abusos. "En cada momento las Asambleas eran interrumpidas por la

65 Se ratifica esta limitación para los militares en el Reglamento para las quejas en el ámbito militar de 11 de septiembre de 1972 y en la Ley sobre el servicio civil de los objetores de conciencia de 28 de septiembre de 1994.

66 Obra citada, pág. 8. 
irrupción de ciudadanos, a veces armados, que venían a depositar sus peticiones sobre los temas más diversos. La petición de Champ de Mars de 17 de julio de 1791 provocó un tiroteo y una matanza» ${ }^{67}$. El caos en el ejercicio del derecho de peticiones era tal, que no producía más efecto que su constatación. Incluso algunas peticiones eran eminentemente curiosas y extravagantes, como la que el 25 de diciembre de 1796, realizó un ciudadano ante el denominado Consejo de Quinientos, que pedía poder "contraer matrimonio con su suegra"68.

Pese a todo, la Constitución de 1791, incorpora por primera vez al constitucionalismo francés, el derecho de petición. Lo hace en su Título I, dedicado a las disposiciones fundamentales garantizadas por la Constitución, y de forma concreta en su artículo 3 establece que ésta garantiza como «derechos naturales y civiles:... la libertad de dirigirse a las autoridades constituidas con peticiones firmadas individualmente». Además, establece como garantía, que "el poder legislativo no podrá dictar ley alguna que atente u obstaculice el ejercicio de los derechos naturales y civiles consignados en el presente título, y garantizados por la Constitución...".

La Constitución de 1793, en su artículo 32, también recogió el derecho de petición, variando únicamente el nombre ante quien debía de ejercitarse, que en la primera es la "autoridad constituida", y en ésta última son los "depositarios de la autoridad pública». El Texto de 1799 introduce la posibilidad de dirigirlas a la autoridad constituida y a la Tribuna (Asambleas públicas). Con la Carta Constitucional de 1814, otorgada por Luis XVIII sólo se reconocen las peticiones realizadas a las Cámaras, que habrán de ser por escrito, y para evitar coacciones, se prohibe entregarlas personalmente. Con esta misma redacción y condiciones pasará a la Carta Constitucional de 1830 y 1848, si bien se restringe en los textos de 1852 y 1870 . En la Constitución de 1946, no se referencia el derecho de petición, al igual que ocurre en la vigente de 1958.

\subsection{Italia}

Escaso ha sido el estudio del derecho de petición por parte de la doctrina italiana, y los pocos autores que se acercan al tema parten

67 Voz "Peticiones», en la obra de VV.AA.: Historia y Diccionario de la Revolución Francesa, Cátedra, Madrid, 1989, pág. 924.

68 Ibidem. 
desde la vigencia del Estatuto Albertino, de 4 de marzo de $1848^{69}$. En él se establece en su artículo 57 , como requisito para ejercer la petición, el ser mayor de edad y se imposibilita la presentación personal ante las Cámaras.

Pese al reconocimiento constitucional citado, su ejercicio fue muy escaso, probablemente debido, como manifiesta Orlando, «a la indiferencia con que era tratado por la cámara y el desprecio que mostraba el poder ejecutivo» 70 .

Prácticamente toda la doctrina de la época reconoce el poco uso de este derecho, y lo atribuye a la incapacidad de adaptarse al derecho público moderno, o como manifiesta Orlando, "es natural que haya disminuido su importancia frente a medios incomparablemente más potentes, como es la imprenta, la reunión, la asociación: de tal manera que cuanto más sean estos últimos garantizados $y$ ejercitados, tanto más deberá el primero perder eficacia» ${ }^{71}$.

También conviene recordar que el derecho de petición se ejerce ante las Cámaras, y tiene sentido en las peticiones con un contenido de carácter genérico, por el contrario cuando la petición es individual las cámaras no pueden ocuparse de la impartición de la justicia ni de la equidad, con lo cual en su inmensa mayoría no son contestadas, lo que conduce al derecho de petición a una via muerta.

Durante el régimen fascista, y con la constatada represión de cualquier medio de participación social y política, el derecho de petición en Italia acaba por desaparecer.

Con la entrada en vigor de la Constitución de 1947, su artículo 50 establece que "todos los ciudadanos pueden dirigir peticiones a las Cámaras solicitando medidas legislativas o exponiendo necesidades comunes». Como puede observarse el derecho de petición reconocido no es el genérico, como lo entendemos en nuestro ordenamiento jurídico, sino más bien es asimilable al que regula nuestra Constitución en su artículo 77.1, lo que le induce un carácter político, y con el fin de obtener un bien común. En consecuencia no se reconoce un

69 A pesar de que existen constituciones anteriores que reconocen este derecho, como es el caso de la Constitución Cispadana de 1798 y la Constitución de la República Cispaldina de 1797, ambas fuertemente influenciadas por la Constitución Francesa de 1791.

70 Orlando, V. E.: Principi di Diritto Costituzionale, Florencia, 1928, pág. 306.

71 lbidem, pág. 307. 
derecho de petición, que puede ejercerse de forma individual y que tenga como contenido cualquier pretensión del ciudadano.

De esta forma la interpretación que en la actualidad tiene el derecho de petición en Italia está íntimamente conectada con el artículo 21 de la Constitución, que reconoce que utodos los ciudadanos tienen el derecho de manifestar libremente su propio pensamiento, de palabra, por escrito o mediante otro medio de difusión». El derecho de participación en el ordenamiento jurídico que estudiamos carece de carácter político, entendido como el ejercicio directo de una función pública. Ha de entenderse más como derecho público que realiza una función singular, es pues, un derecho cívico de comunicación o de relación entre el ciudadano y los poderes públicos.

Pese a todo, pueden entenderse paliadas estas deficiencias en virtud de que este derecho tiene un extenso reconocimiento en el ámbito local, sobre todo a partir de la Ley sobre descentralización y participación de los ciudadanos en la administración local de 1976, que vienen a reforzar el carácter participativo de los ciudadanos, y que de forma concreta establece en su artículo 1 que se promueve "la participación popular en la gestión administrativa de la comunidad local».

En lo relativo al ámbito subjetivo del derecho, se le reconoce a los extranjeros y apátridas, si bien no con una cobertura constitucional y sí legislativa. Es en el ámbito de la extensión de los sujetos singular la Constitución de 1947, dado que no limita el ejercicio de este derecho a los militares, es más, el Tribunal Constitucional italiano en sentencia relativa a la restricción de los derechos fundamentales en el ámbito militar, declaró inconstitucional el artículo 180 del Código Penal Militar, que calificaba como delito de sedición militar "la presentación colectiva, realizada al menos por diez militares, o por uno solo previo acuerdo con los otros, de una instancia, memorial o reclamación, de forma escrita $u$ oral, por cuestiones atinentes a la disciplina o al servicion ${ }^{72}$.

\subsection{Unión Europea}

En el ordenamiento comunitario europeo, a diferencia de los ordenamientos nacionales, no hay una tradición en la regulación del

72 Sentencia del Tribunal Constitucional de Italia $n .^{\circ} 126$, de 2 de mayo de 1985. 
derecho de petición, es más, en los tratados originarios no se recogía este derecho. Su origen se encuentra en la capacidad de autoorganización de la entonces denominada Asamblea, en cuyo reglamento se preveia la posibilidad de dirigir peticiones a la misma ${ }^{73}$.

En 1981 la reforma acometida por M. Luster del artículo 128.1 del Reglamento de la Asamblea establecía que «todo ciudadano de la Comunidad tendrá derecho a presentar, a título individual o en asociación con otros ciudadanos peticiones o quejas al Parlamento Europeon. Con ello se corregía la ausencia a toda referencia de ejercer este derecho por los "ciudadanos europeos»" 74 .

Con posterioridad, el 12 de abril de 1989, el Parlamento Europeo aprobó dos textos normativos en los que insiste en la importancia del derecho de petición: la Declaración de los Derechos y Libertades Fundamentales y la Declaración Interinstitucional adoptada de forma conjunta por el Parlamento Europeo, la Comisión y el Consejo en relación al derecho de petición. En el primero de ellos se hacia referencia al derecho que tiene toda persona a presentar, por escrito, solicitudes o quejas al Parlamento Europeo, y la facultad de aquél de regular su ejercicio como derecho fundamental ${ }^{75}$. El segundo de los textos se comprometía a dar al Parlamento Europeo la colaboración necesaria para el tratamiento eficaz de las peticiones, estableciendo la intención de fomentar la costumbre de los ciudadanos europeos de formular peticiones ante el Parlamento Europeo ${ }^{76}$.

Como puede comprobarse el tratamiento de estos textos respecto del derecho de petición es de derecho fundamental, por el contrario su regulación no viene establecida en ningún tratado constitutivo. Tampoco parece propio que si a un derecho se le otorga el máximo rango, se establezca que ha de fomentarse y que por tanto no es vinculante, existiendo únicamente una obligación moral para las tres instituciones de tener en cuenta las peticiones formuladas ${ }^{77}$.

73 Reglamento de la Asamblea Común de la CECA de 1953.

74 El artículo 48.1 del Reglamento de la Asamblea con anterioridad a 1981 establecia que «las peticiones deben mencionar el nombre, la profesión, la nacionalidad y el domicilio de cada uno de los firmantes". de 1989.

75 Artículo 23 de la Declaración, ver DOCE núm. C 120/51, de 16 de mayo

76 Declaración Interinstitucional de 12 de abril de 1989. DOCE núm. C 120/90, de 16 de mayo de 1989.

77 En el mismo sentido se pronuncia Blázouez Peinado, M. ${ }^{a}$ D.: La ciudadanía de la Unión Europea, Valencia, 1998, págs. 292 y 293. 
Afortunadamente el Parlamento Europeo fue consciente de la insuficiencia normativa de este derecho y pretendió su inclusión en un tratado, y exigió normas jurídicas obligatorias y efectivas en relación con el derecho de petición.

Los esfuerzos del Parlamento Europeo dieron su fruto en el Tratado de la Unión Europea, de forma tal que se reconoce como derecho de los ciudadanos europeos la posibilidad de elevar peticiones al Parlamento, de ésta forma se "constitucionaliza» el derecho, y como consecuencia se limita la posibilidad de que el Parlamento restrinja su ejercicio, a pesar de que había sido el propio Parlamento su mejor valedor.

La importancia de este reconocimiento no es tanto por la inclusión de un contenido más en el catálogo de los que pueden ejercitar los ciudadanos europeos, como porque es un germen de unos futuros derechos políticos.

Tras la revisión de Maastricht, el artículo 21 recoge el derecho de todo ciudadano de la Unión "de petición ante el Parlamento Europeo, de conformidad con lo dispuesto en el artículo 194". Este artículo establece que este derecho puede ser ejercido por "cualquier ciudadano de la Unión, así como por cualquier persona física o jurídica que resida o tenga su domicilio social en un Estado miembro". Conviene advertir, que en el mismo artículo, se regulan también las quejas ante el Defensor del Pueblo, ello tiene una intencionalidad concreta, y no es otra que la de agrupar mecanismos que faciliten la participación ciudadana, y a los cuales se les dota de carácter instrumental para la protección jurisdiccional de los derechos de los ciudadanos de la Unión.

En cuanto a la regulación en ámbito parlamentario, el Anexo VI del Reglamento del Parlamento Europeo ${ }^{78}$ (en adelante RPE), en su número $\mathrm{XIX}$, se establece la Comisión de Peticiones, que userá competente para los asuntos que se refieran a las peticiones, su examen $y$ el curso que proceda darles» ${ }^{79}$.

78 En su versión de octubre de 1993.

79 Con anterioridad, de las peticiones conocía la Comisión de Justicia, después fue competente la Comisión de Reglamento, y por último se creó una comisión específica. Se debe ello al considerable y progresivo aumento del número de peticiones. Durante los años $1977 / 78$ se tramitaron 20 peticiones, durante los años $79 / 80$ se aumentó a 80 peticiones, en los años 1983/84 ya eran más de 100 la peticiones, superando las 250 en el año 1985/86. 
En lo referente al ejercicio concreto del derecho, el artículo 156 del RPE es sumamente preciso en el establecimiento de requisitos, así su apartado segundo requiere que en todas las peticiones conste la profesión, la nacionalidad y el domicilio de cada uno de los firmantes. El apartado tercero establece que las peticiones deberán redactarse en una de las lenguas oficiales de la Unión Europea. Se inscribirán en un registro por orden de entrada (apartado cuarto). El Presidente remitirá las peticiones recogidas al Registro a la Comisión competente, la cual determinará si inciden en el ámbito de actividades de la Unión Europea (apartado cinco). Las peticiones que la Comisión «declare improcedentes se archivarán, con comunicación al peticionario de la decisión y los motivos de ésta" (apartado seis). En todo caso la Comisión puede sugerir al peticionario que se dirija a la autoridad competente del estado miembro, o de la Unión Europea. Si lo considera oportuno también puede dirigir la petición al Defensor del Pueblo Europeo.

Una vez las peticiones en poder de la Comisión, en virtud del artículo 157 del RPE, puede elaborar un informe o dictar un pronunciamiento. Cuando se trate de peticiones que propongan la modificación de disposiciones legales en vigor, la Comisión podrá solicitar opinión a otras Comisiones. También puede prever audiencias o enviar a algunos de sus miembros al lugar de los hechos para comprobarlos, pudiendo en todo momento solicitar documentos, información y acceso a cualquier servicio.

El apartado cuarto del articulo 157 posibilita que la Comisión solicite una votación en el Parlamento sobre las propuestas de resolución elaboradas por ella. Asimismo, la Comisión puede solicitar al Presidente del Parlamento que remita su opinión tanto al Consejo como a la Comisión.

Por último el artículo 158 RPE establece que las peticiones inscritas, así como las decisiones más importantes en relación con el procedimiento aplicado a su examen, serán anunciadas al Pleno, y figurarán en el acta de la sesión.

A partir de 1990, la Comisión de Peticiones agrupa en dos a éstas, para darles distinto tratamiento. De esta forma, las peticiones cuya finalidad última es una solicitud, en la que se pide al Parlamento que se pronuncie sobre un aspecto de carácter general, y que normalmente tienen contenido político, abre un abanico de posibilidades de actuación muy grande al Parlamento, que va desde remitirle al peticionario los textos de la Unión vigentes y aplicables en el caso, hasta elaborar un informe o proponer una resolución. Si la petición tie- 
ne un carácter individual, y más de interés personal que colectivo, lo que viene denominándose como "petición-queja», lo normal es que el Parlamento intente un arreglo amistoso, y ante la imposibilidad de llevar a cabo éste, remitirlo a un procedimiento administrativo o judicial. En la práctica, la Comisión de Peticiones suele recurrir de los servicios de la Comisión, quien actúa con un carácter coactivo o de intermediación en las relaciones entre los peticionarios y los órganos extracomunitarios. En la práctica, la mera intermediación de la Comisión hace que las autoridades de los Estados miembros resuelvan en la mayoría de las ocasiones las peticiones. En los supuestos en los que no es posible llegar a una solución, la principal herramienta de que dispone la Comisión de Peticiones para satisfacer al peticionario, es poner en funcionamiento el artículo 169 del Tratado de la Unión, en virtud del cual, si la Comisión "estimare que un Estado miembro ha incumplido una de las obligaciones que le incumben en virtud del presente Tratado, emitirá un dictamen motivado al respecto, después de haber ofrecido a dicho Estado la posibilidad de presentar sus observaciones. Si el Estado miembro de que se trate no se atuviere a este dictamen en el plazo determinado por la Comisión, ésta podrá recurrir al Tribunal de Justicia». El problema aquí es que la Comisión de Peticiones requiere de la intervención de un órgano comunitario, la Comisión, para interponer el correspondiente recurso ante elTribunal de Justicia, ya que ella carece de legitimación, y tiene limitada su puesta en práctica al incumplimiento o violación del Derecho de la Unión por parte de un Estado miembro, con lo cual deja fuera de su ámbito de actuación los incumplimientos o irregularidades de las instituciones comunitarias.

También puede la Comisión de Peticiones, utilizar otra institución comunitaria como instrumento para hacer efectivas las resoluciones que emita en relación a un derecho de petición. De esta forma, el Parlamento puede, en virtud del artículo 136 de su Reglamento, poner en funcionamiento una comisión de investigación, dado que se establece en él la posibilidad cuando se den "contravenciones de la legislación comunitaria o en los supuestos de mala administración en la aplicación del Derecho comunitarion.

Por último, conviene hacer referencia a un problema intrínseco a la formación y desarrollo de la Unión Europea en relación a la protección de los derechos fundamentales, y que no es otro, que la posibilidad de su protección por parte de las instituciones comunitarias al margen de la aplicación del Convenio Europeo de Derechos Humanos. Hemos de partir en este asunto de la reiterada jurisprudencia del Tribunal de Justicia, en virtud de la cual se establece que los derechos 
humanos forman parte integrante del ordenamiento jurídico comunitario, lo cual a su vez ha sido ratificado por todas las instituciones comunitarias.

Conviene también recordar a este respecto, que el Convenio Europeo de Derechos Humanos no recoge el derecho de petición, sin embargo, la Declaración del Parlamento Europeo sobre derechos y libertades fundamentales ${ }^{80}$, si establece en su artículo 23 , que "toda persona tiene derecho de presentar por escrito peticiones o quejas al Parlamento Europeon. También conviene destacar, que la Carta de los Derechos Fundamentales de la Unión Europea, en su artículo 42 regula de forma específica el derecho de petición, cuando recoge que "todo ciudadano de la Unión o toda persona física o jurídica que resida o tenga su domicilio social en un Estado miembro tiene el derecho de petición ante el Parlamento Europeo".

Es frecuente que el Parlamento reciba peticiones que reclaman su intervención en el ámbito de los derechos humanos, bien solicitando su protección, bien para que haga de intermediario a través de las delegaciones interparlamentarias con los Estados miembros. Es más la Comisión de Peticiones ha examinado quejas relativas a las condiciones de los detenidos, a la objeción de conciencia y al derecho a un juicio justo. Pero esta situación es jurídicamente anómala dado que en virtud del principio de división de poderes, ni la Comisión de Peticiones, ni el Parlamento Europeo, pueden dilucidar cuestiones relativas a los derechos y libertades fundamentales.

Esta situación dejará de ser conflictiva en el momento que se incorpore la Carta Europea de Derechos Fundamentales a los tratados y tenga vigencia plena, dado que en ningún caso el Parlamento Europeo podrá realizar funciones jurisdiccionales, incluso en el ámbito de los derechos fundamentales. De esta forma cuando la Comisión reciba peticiones con un contenido de reclamación o exigencia de cumplimiento de derechos fundamentales deberá limitarse a referir los principios que disciplinan la materia, no podrá resolver al respecto del fondo de la cuestión, y en última instancia podrá indicar al peticionario que ejercite los derechos que le reconoce la legislación europea en este ámbito. 


\section{CONCLUSIONES}

Una vez analizados de forma pormenorizada los aspectos más esenciales del derecho de petición, conviene obtener algunas conclusiones, que nos sirvan para agrupar las ideas aportadas, y en todo caso, para resaltar las conclusiones más significativas a las que hemos llegado.

Ha quedado constatado, que el derecho de petición ha sido históricamente un derecho relevante, tanto por ser el origen de otros muchos derechos de los que hoy denominamos fundamentales, como porque ha sido una vía de participación del ciudadano en la actividad politica, a la vez que un medio de solventar conflictos. Estas conclusiones nos inducen a atribuir al derecho de petición una característica fundamental, su versatilidad. Ha sido capaz de adaptarse a diversos contextos sociales, políticos $y$ jurídicos, $y$ en todos ha sido útil.

Las razones apuntadas justifican su reconocimiento en los textos jurídicos más importantes de cada época, y en las constituciones con posterioridad. Prueba irrefutable de ello es que ninguna de las constituciones españolas ha omitido el derecho de petición. Es más, la Constitución vigente opta por incluirlo junto con los derechos más esenciales del ciudadano, y como consecuencia de ello, entre los más protegidos, lo cual es criticable, como quedó argumentado en el apartado tercero, pero no merecedor de desconstitucionalizar este derecho.

Como en todo estudio jurídico, y más en los relativos a derechos, tanto el contenido esencial como, la naturaleza jurídica, son elementos determinantes para su correcto entendimiento. Respecto del primero, conviene recordar que queda delimitado por cuatro elementos imprescindibles. Es un derecho de reconocimiento genérico y que no puede limitarse su ejercicio ni a los extranjeros, ni a las personas juridicas. Es una pretensión que se ejercita ante cualquier poder público, y relativo a cualquier materia, de su ejercicio no puede derivarse perjuicio alguno y existe la obligación del destinatario de contestar motivadamente.

Por lo que respecta a su naturaleza jurídica, como hemos recogido, la calificación doctrinal es muy diversa, y ninguna exenta de fundamento, sobre todo, por la cita versatilidad del derecho. Pese a todo, es preceptivo recordar que en el derecho que estudiamos confluyen dos vertientes. Una primera que atiende a intereses individuales, y que se constituye en un mecanismo útil del ciudadano para ayudarle en su 
relación con el complejo sistema administrativo y burocrático. A la vez, también desde la perspectiva individual el derecho de petición es útil, puesto que pone en conocimiento de los poderes públicos desde funcionamientos deficientes, a vacíos legales. Con ello el derecho de petición se identifica como un derecho de libertad, de expresión y también con la pretensión de solventar una irregularidad.

La segunda vertiente del derecho de petición, por el contrario, lo acerca más a un derecho participativo y con pleno contenido político. El derecho de petición puede ser un catalizador de sentimientos compartidos por grupos de ciudadanos, que no quieren pasar por el tamiz de los partidos políticos, determinados grupos sociales, o por los medios de comunicación. Pero al no estar delimitado ni constitucional ni legalmente el contenido de las peticiones, éstas, ejercitadas de forma colectiva, pueden ser también usadas con fines de interés común.

La delimitación tanto del contenido esencial, como de su naturaleza jurídica, nos fuerzan a distinguir al derecho de petición de otros conceptos, como son la acción judicial, la reclamación, el recurso, la solicitud, la denuncia o las quejas ante el Defensor del Pueblo. En casi todas ellas, el elemento diferenciador es el reconocimiento por parte del ordenamiento jurídico de un procedimiento y contenidos específicos. Pero también es conveniente recordar, que en todas ellas, incluida la petición, existe la obligación del poder público de una actuación y que en todo caso ha de ser acorde a derecho.

En lo referido a los sujetos, la Ley Orgánica 4/2001, ha venido a clarificar definitivamente la indefinición en cuanto al ámbito subjetivo. De esta forma, el derecho de petición es ejercitable tanto por extranjeros, como por personas jurídicas, así como por funcionarios o internos en centros penitenciarios. Queda como única grupo en el que el derecho se ejerce con limitaciones, el de las Fuerzas Armadas. La limitación alcanza únicamente a las peticiones colectivas, y siempre que sean relativas estrictamente al ámbito funcional.

Otros dos aspectos importantes son los requisitos tanto materiales como formales. Respecto de los primeros, tanto el artículo $29 \mathrm{CE}$, como la Ley Orgánica 4/2001, posibilitan la petición al respecto de cualquier materia, siempre que contengan un petitum.

Respecto de los formales, la ley citada, es considerablemente más precisa que la que deroga. Además, rige en la petición, y en lo relativo a los requisitos formales la Ley de Régimen Jurídico de la Administración en todo lo que hace referencia a idiomas, medios electrónicos y contenido necesario de la petición. 
Quizás el aspecto más relevante en este apartado, sea la necesaria contestación motivada del destinatario de la petición, una vez que ésta ha sido admitida a trámite, dado que ésta junto con el petitum, son la esencia del derecho. La resolución de la administración u organismo que contesta a la petición habrá de hacerse en plazo, tres meses, tendrá que ser motivada y contener la forma de solventar aquello que se pide, o de establecer los medios necesarios para su solución. Puede incluso publicarse en los diarios oficiales la contestación. En todo caso, la resolución habrá de ser ajustada a derecho, y de no ser procedente la vía de la petición, el destinatario deberá comunicar al peticionario los recursos jurídicos establecidos para obtener satisfacción de sus pretensiones.

En lo referido a la protección jurisdiccional, ya hemos mencionado que es un derecho superprotegido, acumulándose la vía establecida en el artículo 53.2 CE, es decir el recurso de amparo, la que establece la Ley Orgánica 4/2001, que remite al recurso contenciosoadministrativo, y por último, la que viene regulada en la Ley de Régimen Jurídico (Ley 30/92).

Para terminar estas conclusiones, conviene destacar el reconocimiento $y$ efectividad del derecho de petición en algunos ordenamientos jurídicos. Aquí puede observarse con claridad como partiendo de un similar reconocimiento, su virtualidad es diferente. La vigente Constitución francesa no recoge el derecho, por el contrario la Constitución del Reino Unido sí, pero no se hace de él un uso como derecho de participación social, o como medio útil para el ciudadano en su relación con los poderes públicos. Ha quedado más como una reliquia constitucional, que como un derecho operativo. Por el contrario, en Estados Unidos ha sido $y$ es un derecho vivo, sobre todo en su vertiente colectiva, ha sido herramienta sumamente útil en reivindicaciones sociales de primer orden y se mantiene como mecanismo de participación política directa del ciudadano en los asuntos públicos. En Alemania, a pesar de que es un derecho de tardía aparición, tiene reconocimiento constitucional y ha sido modelado por el Tribunal Constitucional Federal, adaptándolo a las nuevas necesidades, y sobre todo ha sido sumamente útil para cubrir las carencias de la Ley Fundamental de Bonn en cuanto los medios de democracia directa. También es de destacar su configuración negativa, es decir se fundamenta su existencia como medio de defensa ante los poderes públicos, por lo que tiene atribuida una protección del máximo nivel. En Italia también tiene el derecho de petición reconocimiento constitucional, y se interpreta y aplica como libertad de expresión y de manifestación del ciudadano. Curiosamente, ante el poco uso a nivel general, el derecho que 
estudiamos, en Italia ha tenido un desarrollo muy destacable en el ámbito local, donde está profusamente regulado y los mecanismo para hacerlo efectivo son consistentes. También es reseñable, que el ámbito subjetivo, el derecho de petición en Italia no tiene límites, de forma tal que incluso a los militares, les está permitido hacer uso de él, en virtud de la jurisprudencia del Tribunal Constitucional.

Por último, hemos dedicado un apartado algo más extenso al derecho de petición en la Unión Europea. Aquí el derecho muestra una singularidad, ha sido creado y modelado por el Parlamento, $y$ ante él se ejercita. Además se reconoce en el Tratado de la Unión Europea, en la Declaración de Derechos de 1989, y también en la reciente Carta Europea de Derechos. Su desarrollo normativo viene recogido en el Reglamento del Parlamento Europeo, encargando a una Comisión específica la resolución de las peticiones. Pese a todo, la eficacia del derecho se ve debilitada por la propia complejidad organizativa de la Unión. A ello hay que añadir la improcedencia de las instituciones de la Unión para solventar asuntos directamente relacionados con derechos recogidos en el Convenio Europeo de Derechos Humanos, lo que establece una cierta indefinición sobre la efectividad del derecho de petición. 